\title{
Smart Technical Street Furniture Design: Case study of "New Cairo Administrative Capital'"
}

DOI: $10.21625 /$ archive.v1i1.124

\author{
Hala Hassanein ${ }^{1}$ \\ ${ }^{1}$ Assistant Professor - Interior Architecture Design Faculty of Fine Arts - Helwan University
}

\section{Keywords}

futuristic cities; Smart Street Furniture; smart devices; New Technology Design Trends; Information Communication Technology - ICT technology; Information Technology Service Management (ITSM), Q-Methodology

\begin{abstract}
Street furniture has been redefined by the high pace of technology as smart devices that contribute to build future cities. Thus, it is a combination of passion, skills, ideas and tools of Information and Communication Technologies (ICT) ${ }^{1}$ converted into finished products. ICT is a catalyst for cities to address these challenges in a 'smart' manner that links and strengthens networks of people, businesses, infrastructures, resources, energy and spaces. On the other hand, one of the most important components to be adopted for designing Smart Cities is the IT service management $(\mathrm{ITSM})^{2}$. It refers to the entirety of the activities directed by policies, organized and structured to plan, design, operate and control ITSM offered to citizens by adopting a process approach towards management, focusing on their needs and stressing continual improvement.
\end{abstract}

New trends in urban planning are heading to draw a new future- a Smart City that is able to link the physical capital with the social one. Street furniture, as an important element of Smart Cities, is a term used to define objects in public spaces. Such concept is related to the context of wireless ${ }^{3}$ infrastructure and house small-cell units. They are considered -visually- as common and torelabe places to the public.

This research will focus on smart Street-Furniture design as a standard guide for designers and planners of the "New Cairo Administrative Capital", which is currently under construction as the first Smart City in Egypt.

\section{Introduction:}

Street Furniture ${ }^{4}$ is a collective term for objects and pieces of the installed equipment on streets and roads of various purposes. Street-furniture has become a cardinal element of many nations' identities. In other words, it is what makes the streets serve as an astonishing and national landmark that attracts the visitors. Such streetfurniture would be the red telephone boxes of Britain; the residential mail boxes of the United States; and the street lights and metro entrances of Paris. Typical examples of Street Furniture include billboards, lamp posts, and lit signage, phone booths, kiosks, mailboxes, park benches, bike racks, public art, utility poles, traffic signals, information boards, city maps and other structures that have a nearby power source. In order to make

\footnotetext{
${ }^{1}$ Catriona MANVILLE, Gavin COCHRANE, \& Jonathan CAVE, RAND Europe, "Mapping Smart Cities in the EU", 2014, IPOL-ITRE_ET (2014) 507480_EN_2.pdf - p.9

2 Wikipedia, Definition of IT Service Management, https://en.wikipedia.org/wiki/IT_service_management

3 Donald Watson, Alan Platted \& Robert Shibley, 2003, "Time-Saver Standards for Urban Design". McGraw-Hill Companies, P 7.9, 1-7

${ }^{4}$ Wikipedia, , Definition of Street Furniture, https://en.wikipedia.org/wiki/Street_furniture
} 
Street Furniture suitable for small-cell networks, it must be able to accommodate power, antenna and associated fiber and other cabling equipment.

We have considered a number of Smart Cities in the region, namely, the Middle East as well as in the European Union (EU-28). The main focus is on Street Furniture as the core of our research. Dubai has been actively pursuing its ambition to become the world's smartest city by 2017 through the recent launch of a "one-stop shop" mobile app to access government services, and the planned deployment of 100 smart bus stations by early next year is another considered objectives. Most countries of the Middle East, including Bahrain and the United Arab Emirates -UAE, still are in the bottom half of the open-data global rankings because of their limitations pertaining the usage of data via internet.

According to the European Union (EU) rankings ${ }^{5}$, Luxembourg is a European Smart City leader. It ranks the top in the recent ranking mapping Smart Cities across the EU-28 issued by the European Parliament's Committee on Industry ${ }^{6}$. In general, the data of these cities and other countries, such as Paris, Spain and Seoul, were obtained amd examined using online sources of information, like local governments and projects' websites. "New Cairo Administration Capital" is not just about implementing technology for the sake of technology, but rather it follows an informed agenda to combat various urban challenges in Egypt such as growing populations and issues related to basic service delivery, citizen safety, and social inclusion.

\section{The Purpose / Main Emphasis:}

I explored the public space designs of smart cities in order to focus on analyzing the innovative and technological aspects of smart Street Furniture. Then, I will make an analysis of the situation concerning planning the smart, urban, cities design to improve the elements' effectiveness of Street Furniture facilities. Following these line, it gives some advices and recommendations which are helpful to improve the public urban design in a way that responds to the unfavorable factors of the smart considerations of the city. It is essential to seek a scientific method of designing to create a comfortable and pleasant public Street Furniture for the New Cairo Administration Capital. Our main emphasizing will depend on analyzing various technological trends and techniques in designing smart Street Furniture. In other words, an overview on different new devices technologies will be conducted. The desired result of that is to have an enhancement for designing new ideas or trends to be utilized in the manufacture of the materials used in Street Furniture. The ideal criteria for the designers as a general guide for making a scientific curriculum is to keep track of what's new in the Hi-Tec communications.

\section{Methodology and Structure:}

We have taken a conventional approach in the study with a strong emphasis on integrate technical aspects of technology for Street Furniture with the goal of creating smart and connected public spaces. We followed that with in-depth analysis to provide an accurate and objective picture of current available patterns with its related new trends. Based on these insights, we identify examples of good applications and formulate recommendations for future interventions that could influence developments of "New Cairo City" and its contribution to the objectives of EGYPT 2020- 2030. "New Cairo Administration Capital" is planned to having meaningful objectives aligned with its economic vision and its expected tangible outcomes.

Price Waterhouse Cooper - PwC as an international financial organization, published, "The World in 2050" stating that Egypt will achieve the 19th global rank in 2030. The expected GDP will have a total of US\$ 2049bn. As for 2050, 15th place is the expected rank for Egypt with an expected GDP with a total of US\$ 4333bn compared to its current rank. In 2016, Egypt occupied the 21th rank with a total GDP of US\$1105bn.

One of the contemporary approaches in urban planning that has never been applied before in our region is Qmethodology ${ }^{7}$. It is widely accepted as a scientific research method used in various types of businesses. Also, it's a well-structured and increasingly-used research method of measuring different perspectives, attitudes or subjective opinions for developing new ideas- with an emphasis on the human practice and their field of experience.

\footnotetext{
${ }^{5}$ European Union, "EU rankings", http://smart-cities.eu/ranking.html

${ }^{6}$ Dr. Marco Annunizata, "Designing the Smart Cities of the Middle East". General Electric - GE Look ahead. The Economist; 2016, http://gelookahead.economist.com/smart-cities-middle-east-2 $\wedge$

${ }^{7}$ Dr. Joon Sik Kim, Xi'an Jiaotong - Liverpool University, "Mapping Conflicts in the Development of Smart Cities: the Experience of Using Q Methodology for Smart", Gusu Project, Suzhou, China, 2016,CORP2016_13.pdf, p. 2
} 
We will conduct number of a questions (i.e. factual statements) to selected number of authorized governmental officials and others working at non-governmental companies to answer our inquiries in a scientific method to support our findings.

The methodology depends on searchable implementations, questions (Q-Statements) through a brief review of the previous experiences of designing new ideas and trends. Definitely, the trends or ideas are used in Street Furniture and were obtained from various models of Smart Cities around the world.

The methodology and structure will include the following:

\begin{tabular}{|c|l|l|}
\hline 3.1 & Definitions and Concepts Section: & $\begin{array}{l}\text { Provides functioning definitions of Smart Cities, Street } \\
\text { Furniture, environment, related characteristics and describing } \\
\text { design factors. }\end{array}$ \\
\hline 3.2 & $\begin{array}{l}\text { Street Furniture Elements, Materials \& } \\
\text { Analysis of the New Trends Section: }\end{array}$ & $\begin{array}{l}\text { Elements of Street Furniture, materials and analyses of success } \\
\text { design factors with intensive focus on the relationship between } \\
\text { technology-factors and the types of designing the construction } \\
\text { process to prepare a Conceptual Planning Model. }\end{array}$ \\
\hline 3.3 & $\begin{array}{l}\text { The New Cairo Administration Capital' } \\
\text { Planning Section: }\end{array}$ & $\begin{array}{l}\text { Provides an analysis of the successful factors of planning the } \\
\text { city, main aspects, and implementation of the Q-methodology. } \\
\text { Design of Conceptual Planning Model - CPM as criteria or } \\
\text { guide for Street Furniture planners. }\end{array}$ \\
\hline 3.4 & Conclusion Section: & Findings, conclusions and recommendations, \\
\hline
\end{tabular}

\subsection{Definitions and Concepts Section:}

Definition of Technology ${ }^{\mathbf{8}}$ : It is "the collection of techniques, skills, methods and processes used in the production of goods, services or in the accomplishment of objectives such as scientific investigation, or the purposeful application of information in the design, production, utilization of goods, services, and in the organization of human activities". Thus, the street furniture technology design is the collection of purposeful application of information in the design, utilization of public services in a good manner for the organization of, and the benefits of human activities. This section will include Smart Cities (3.1.1) and Street Furniture (3.1.2) respectively.

\subsubsection{Smart Cities:}

From an international perspective, United Nations in its Report of the World Commission on Environment and Development, “Our Common Future9" identified Smart City as “a city that strategically utilizes many smart factors. As in Figure 1, three main pillars should be considered in the definition, namely, planning and management, infrastructure and people.

\footnotetext{
${ }^{\mathbf{8}}$ Wikipedia, "Definition of Technology", https://en.wikipedia.org/wiki/Technology

${ }^{9}$ United Nations UN “Our Common Future” Chapter 1: A Threatened Future, clause 49, http://www.un-documents.net/ocf-01.htm\#1
} 


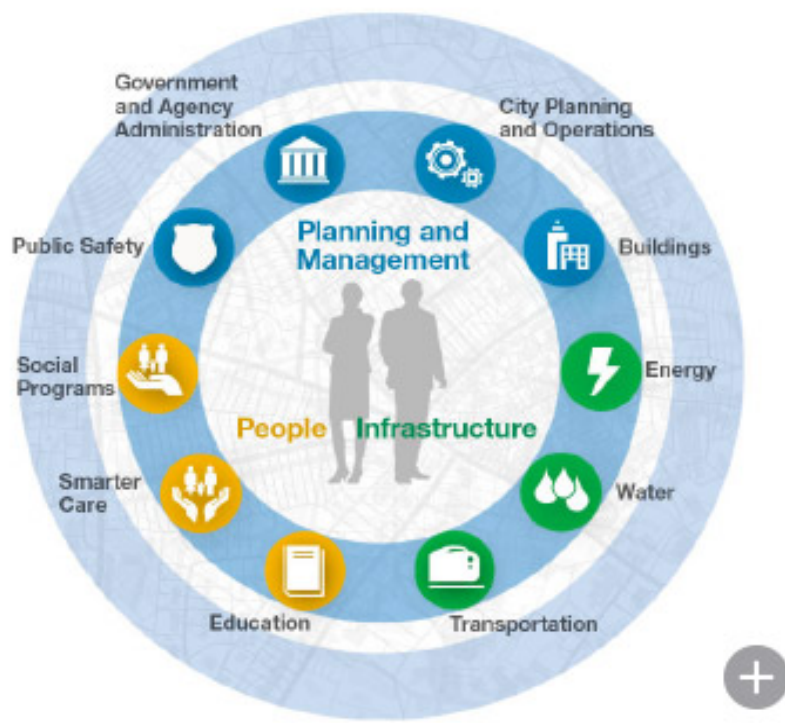

Figure 1 -Elements of Smart Cities

In Figure 1: These pillars are the joint elements for many features of Smart Cities such as Government and Agency Administration; City Planning and Operations; Buildings; Energy; Water; Transportation ${ }^{\mathbf{1 0}}$; Education; Smarter Care; Social Programs; and last but not least, the Public Safety.

The concept of Smart Cities around the world has three characteristics to solve its terminological confusion about its identity and nature of the city as identified in United Nations - UN "Mapping Conflicts in the Development of Smart Cities"11 as summarized in the following table:

\begin{tabular}{|c|c|}
\hline $\begin{array}{c}\text { Smart } \\
\text { Characteristics }\end{array}$ & Definitions \& Implementations \\
\hline $\begin{array}{l}\text { Concept of } \\
\text { Smart Cities } \\
\text { as } \\
\text { "Engineering" }\end{array}$ & $\begin{array}{l}\text { Emphasizing the degree of communication, interaction, sensor networking necessary to achieve } \\
\text { level of smartness nature including but not limited to: } \\
\text { - } \quad \text { Wired and wireless connectivity to the highest standards of bandwidth. } \\
\text { - } \quad \text { Operation center to operate, maintain, and control all activities. } \\
\text { - } \quad \text { Air pollution counter-measures, and monitoring systems. } \\
\text { - } \quad \text { Smart water utility pipe leak, irrigation, and waste management. } \\
\text { - } \quad \text { Stimulating green behavior, smart buildings, running track, and elderly care systems. } \\
\text { - } \quad \text { Public parking availability prediction, smart car parking and interactive street sensing. }\end{array}$ \\
\hline $\begin{array}{l}\text { Concept of } \\
\text { Smart Cities } \\
\text { as } \\
\text { "Science" }\end{array}$ & $\begin{array}{l}\text { Giving special importance to innovative technologies with deep involvement of science to } \\
\text { improve the way people live, and work including: } \\
\text { - Information systems should conform to the best available current standards for } \\
\text { interoperability between information technologies (IT) systems in general; and for } \\
\text { interoperability in the built environment, and physical infrastructures. } \\
\text { - The model of city information includes: commuter information model, mobile payment, and } \\
\text { smart fit navigation, etc. }\end{array}$ \\
\hline $\begin{array}{c}\text { Smart } \\
\text { Characteristics }\end{array}$ & Definitions \& Implementations (Continue) \\
\hline $\begin{array}{l}\text { Concept of } \\
\text { Smart Cities } \\
\text { as } \\
\text { "Studies" }\end{array}$ & $\begin{array}{l}\text { Third view is to investigate what Smart Cities mean for the economy and society. The } \\
\text { complexity of Smart Cities is inseparable from the economic, social, environmental, and } \\
\text { culture. New patters of technology integration have encouraged the society to be "more" } \\
\text { interconnected and interactive, not only to share information, but also to allow a novel form of } \\
\text { transactional relationship between different actors in the society. }\end{array}$ \\
\hline
\end{tabular}

Nowadays, "New Cairo Administration Capital" is under construction (i.e. build-in progress) as a Smart City based on the aggregation of these characteristics: Engineering, Science and Studies. Since culture and

\footnotetext{
10 New Jersey Department of Transportation, 2008, USA, Pennsylvania Department of Transportation

11 Dr. Joon Sik Kim, Xi'an Jiaotong - Liverpool University, Mapping Conflicts in the Development of Smart Cities: the Experience of Using Q Methodology for Smart, Gusu Project, Suzhou, China, 2016, CORP2016_13.pdf, p. 1-2
} 
technology may influence Street Furniture design with the addition of new requirements for the Egyptians needs, all -together- should be synchronized and interacted.

A Smart City ${ }^{12}$ is one with at least one initiative or more of the following six smart characteristics, guidelines ${ }^{13}$ of urban smartness, design, and its related applications as follows:

- Smart Mobility: $\quad$ e.g. Emission free transport, advanced parking, and accessibility

- Smart Economy:

- Smart Living,:

- Smart Governance:

- Smart People:

- Smart Environment: e.g. green environment, sustainable building, and water management

Smart Environment: As one of above main characteristics, smart environment definition and its different types, is listed within "50 Sensor Applications for a Smarter World"- by Libelium ${ }^{14}$ that includes fire detection by monitoring of combustion gases and fire conditions to define alert zones (public housing \& governmental bodies).

One of the Hi-Tec devices used in this regard, is a synthetic tree in Boston, USA as follows:

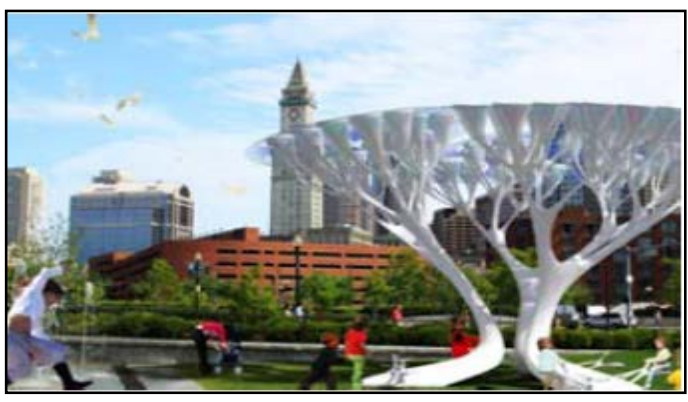

Figure 2 - A Synthetic Urban Tree - Boston USA

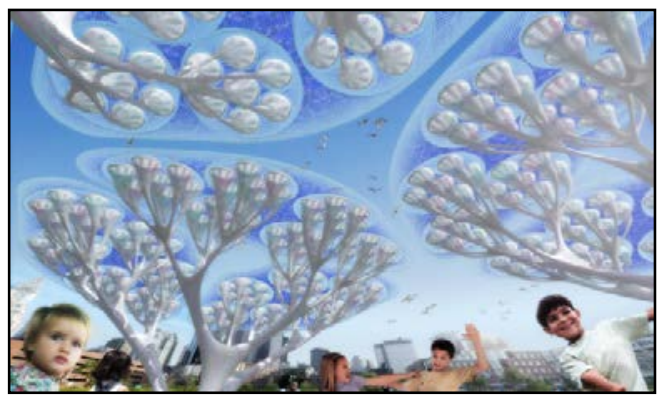

Figure 2a - A Synthetic Urban Tree "Humidity Swing”

As shown in (Figs 2-2a-2b), the above example was design in Boston, USA, as one of the most effective and efficient method to solve the issue of air pollution which provides controlling the $\mathrm{CO} 2$ emissions, pollution emitted by cars. During late October of 2010, the SHIFT Boston ${ }^{15}$ recruited Mario Caceres and Christian Canonico from Paris, to develop a synthetic urban tree that could benefit the City of Boston.

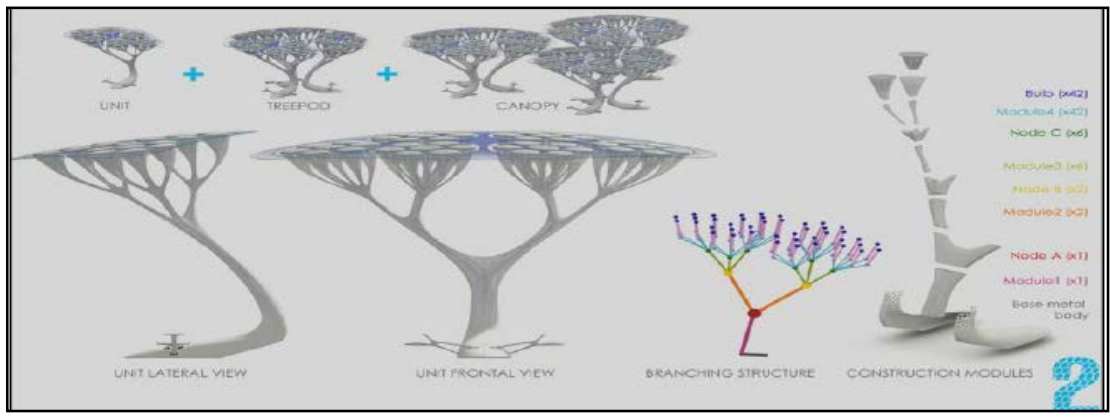

Figure 2b - Construction Modules of Synthetic Urban Tree

It's an urban intervention which contains a system that is capable of removing carbon dioxide from the air and releasing oxygen using a carbon dioxide removal process called "humidity swing". In addition to cleaning the air, it will also generate energy with solar energy panels while harvesting kinetic energy through an interactive seesaw that visitors can play with at the Treepod's base.

\footnotetext{
12 UN Commission on Science and Technology for Development, "Issues Research on Smart Cities and Infrastructure", 2016, p. 11, http://unctad.org/meetings/en/SessionalDocuments/CSTD_2015_Issuespaper_Theme1_SmartCitiesandInfra_en.pdf

${ }^{13}$ China Development Bank Capital, 2015, "Six Smart Guidelines, CDBC's Green and Smart Urban Development Guidelines", Green \& Smart, Six-Smart Guidelines_2.pdf, p 14-18

${ }^{14}$ Libelium, "50 Sensor Applications for a Smarter World", Smart Environment,

http://www.libelium.com/resources/top 50 iot sensor applications ranking/

${ }^{15}$ SHIFT BOSTON, USA, "BOSTON TREEPODS 2011", 2011, http://shiftboston.org/competitions/2011_treepods.html
} 
The other means by which those above six characteristics of "Urban Smartness" are achieved include a range of components: technologies; material, organizational and knowledge inputs; processes; and norms or standards. Our study over "New Cairo Administration Capital" is to conclude whether the majority of these six characteristics are properly applied and accounted for within the planning phase and eventually in the implementation process or not.

\subsubsection{Smart Street Furniture:}

As shown in Figure 3, the Designs of the smart Street Furniture has become a symbol for the concept of Smart Cities and public places that use technology to enhance services, reduce costs and resource consumption to enable residents to engage them effectively and actively with each other (Fig 3).

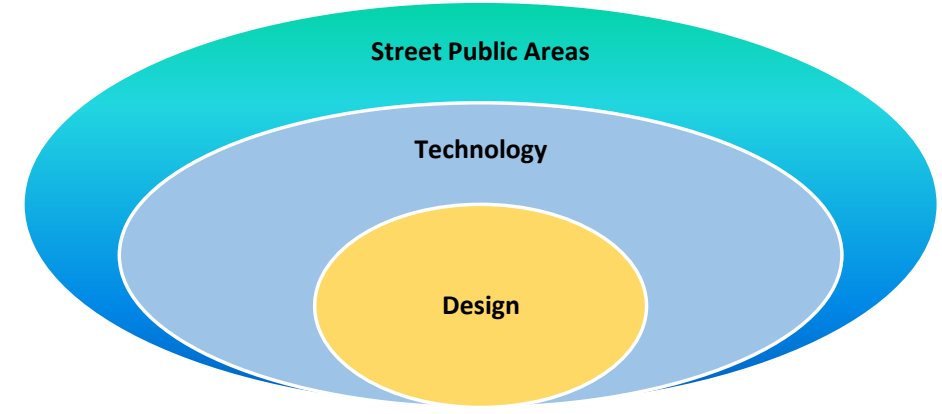

\begin{tabular}{|c|c|c|}
\hline $\begin{array}{c}\text { Street Public Areas } \\
\text { (Landscape) }\end{array}$ & Technology & Design \\
\hline - Urban Planning & - Smartphone Apps & - Public Art \\
- Circulation & - WiFi networking & - Media Content \\
- Street Furniture, & - ICT / ITSM, Real time & Architecture Design \\
Lighting & - Data collection \\
- Transit Facilities & - Data process software & \\
\hline
\end{tabular}

Figure 3 - Concepts of Smart Street Furniture

As cities look for economical ways (i.e. smart economy) to enhance Street Furniture, it offers unique technology solutions by leveraging their existing assets such as streetlights and outmoded phone booths. Cities are creating next generation infrastructure by linking them to public carrier or city networks. These connections facilitate new services and benefits the citizens and visitors in the form of Wi-Fi, mobile charging, interactive city maps, and real-time city information and alerts. In addition, cities can gather air quality, traffic, and noise data from sensors on the smart Street Furniture to better manage the city dynamics which will boost the neighborhood's safety.

\section{Categories of Technology Systems:}

\section{A. Tools of ICT Technologies ${ }^{16}$ :}

IT Service Management, ITSM is a general term that describes a strategic approach for designing, managing and improving the way information technology (IT) is used. The goal of every IT Service Management framework is to ensure that the right processes, people and technology are in place so that the Smart City can meet its business and social goals. The common tools include:

- Cellular Network: It is a communication network where the last link is wireless. The network is distributed over land areas called cells, each served by at least one fixed-location transceiver, known as a cell. It basically refers to having many small interconnected transmitters as opposed to a master one.

- Digital: It is a type of transfer that involves breaking a message or form of communication between two machines down into binary code. Binary code consists of all ones and zeros, and it could be reassembled upon being read by another piece of equipment that utilizes the digital technology.

- Mechanical: It is the application of engineering principles and technological developments to the creation of useful machinery or products.

\footnotetext{
${ }^{16}$ Sara Bartolini, 2009, “Smart Sensors for Interoperable Smart Environment“- PhD, UNIVERSITÀ DI BOLOGNA, p. 80 (Table 5.3) http://amsdottorato.unibo.it/23D360A0-8FEC-4637-A7FC-BD4C2AFA9319/FinalDownload/DownloadId337A21BDD2E613292EFBC428A1D24AD5/23D360A0-8FEC-4637-A7FC-BD4C2AFA9319/2576/1/Bartolini_Sara_tesi.pdf
} 
- Optical: It refers to anything that relates to light or vision, whether it is visible light or infrared light- that performs a specific function.

- Virtual: In computing, virtualization refers to the act of creating a virtual version of something, including virtual computer hardware platforms, storage devices, and computer network resources.

- Vision: It is an integrated engineering system providing world-class solutions and services in electronics, land systems and provides a wide array of high-value products to blue-chip customers.

The first four technologies are used widely in designing, planning, implementing new approaches and applications for Smart Cities as well as Street Furniture, whereas the last two points are less used due to different reasons.

\section{B. Tools of Energy technologies ${ }^{17}$ :}

It is an interdisciplinary engineering science having to do with the efficient, safe, environmentally friendly and economical extraction, conversion, transportation, storage and use of energy. It is targeted towards yielding high efficiency while skirting side effects on humans, nature and the environment.

\section{Design Principles ${ }^{\mathbf{1 8}}$ :}

As shown in Figure 4, the premise of Street Furniture design is that it should be people-oriented. It is the core idea of Street Furniture design as located in the center. Based on this premise, three main principles are developed as: functional, unity, and identity. The three principles are in balanced positions and linked in the model. It implies that the principles are equally important, coordinated and interflowed with each other as follows:

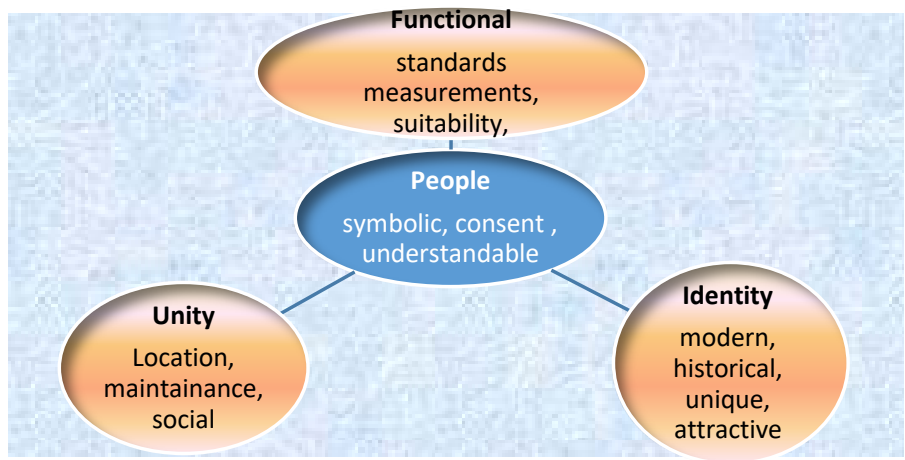

Figure 4 - Design Principles of Street Furniture

- Functional: It must be designed according to certain standards from the perspective measurements, architectural, in unique form, usage, comfort, quantity accessibility, functional suitability, and suitability of material as in Figure 5. A real example exists in Dubai as air-conditioned smart shelters offering multiple services, like free Wi-Fim, and it comes in different types of kiosks.

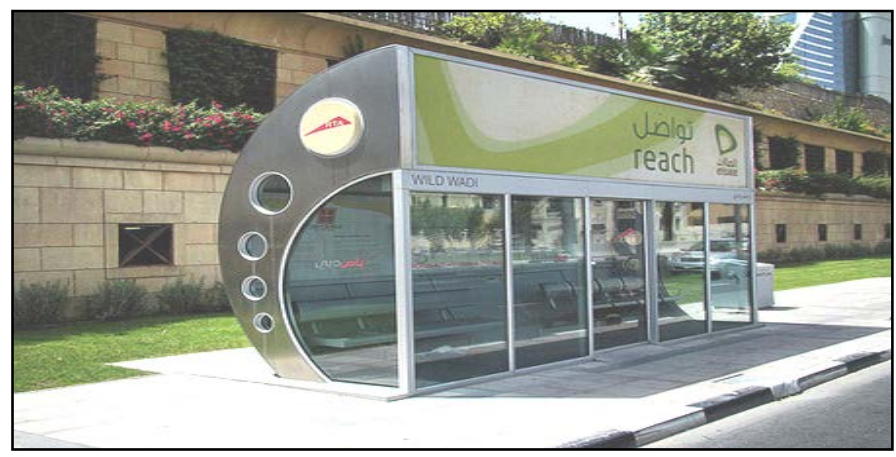

Figure 5 - Dubai, Smart Shelters

\footnotetext{
${ }^{17}$ Wikipedia, Definition of "Energy Technology', https://en.wikipedia.org/wiki/Energy_technology

18 Ghorab, 2014 , Istanbul, Turkey, "Evaluation of Street Furniture according to basic design principles", Design Principles - Materials, p.6
} 
- People Oriented: The criteria that affect to what extent Street Furniture design makes a difference or how much it is liked by users. It should indicate to what extent it is understandable, meaningful, symbolic and creating visual richness.

- Unity: Should be compatibility between different types of Street Furniture, compatibility with surrounding, environment and climate must be evaluated carefully; be in color harmony, shape, easily maintained and complying with the social considerations.

- Identity: It should be in modern form, having historical qualities referring to history, culture, tradition life style \& behavior, geographic environment, different, attractive, original/ unique, and in a good location. The most famous two examples for applying design identity within the outlook of Street Furniture are in the Middle East; (Dubai) as Smart Palm, and European Union - EU (Denmark) as Tulpi Seating Units, (Figs 6, 6a,6b):

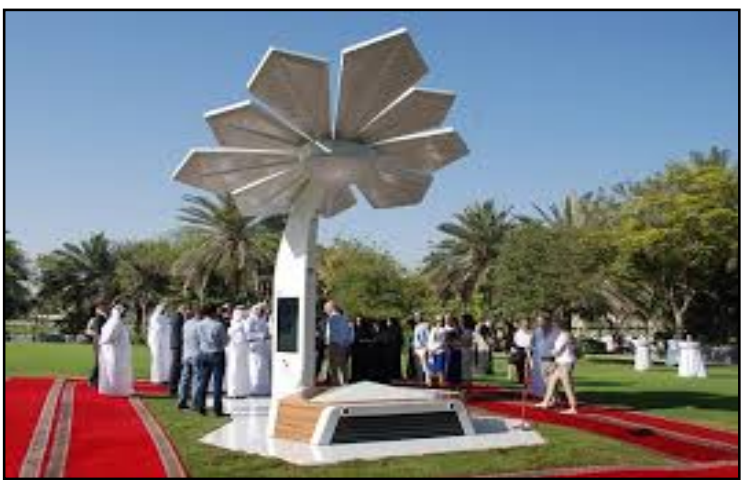

Figure 6 - Dubai, Smart Palm

\section{Dubai:}

Figure 6 - Smart Palm is a green multifunctional device and info-point with $\mathrm{Wi}-\mathrm{Fi}$ access. It made from a combination of fiber-reinforced plastic and concrete topped with nine leaf-shaped photovoltaic modules.

A six-meter-tall palm can generate around 7.2 kilowatt hours, a touch-screen panel giving local details on weather and transportation. Over the next 12 months, Dubai plans to install 103 Smart Palms across the city.

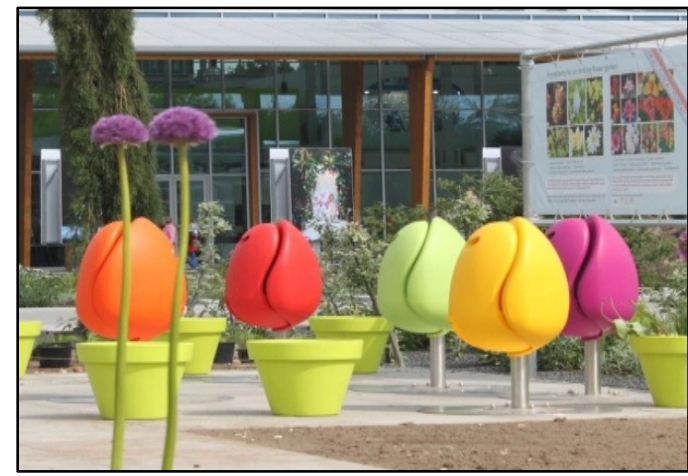

Figure 6a - Denmark, Tulpi Seating Units

\section{Denmark:}

Figure 6a - Tulpi-design is a typical Dutch design. Marco Manders achieved recognition with his Tulpiseats, which is based on the Dutch national flower, the tulip. It allows people to orient seats to meet specific social needs; the Tulpi ${ }^{19}$-seat is made from plastics that fall into the category of LLDPE (Linear lowdensity polyethylene) and stainless steel. No toxic chemicals are used to treat the Tulpi-seat. Polyethylene is an essential biologically inert solid and considered as non-toxic.

\section{Cairo:}

The identity aspects of "New Cairo Administration Capital"20" as the unique designing approach reflecting its Islamic identity such as street seating which are designed based on the Islamic patterns as shown herewith Figure 6b

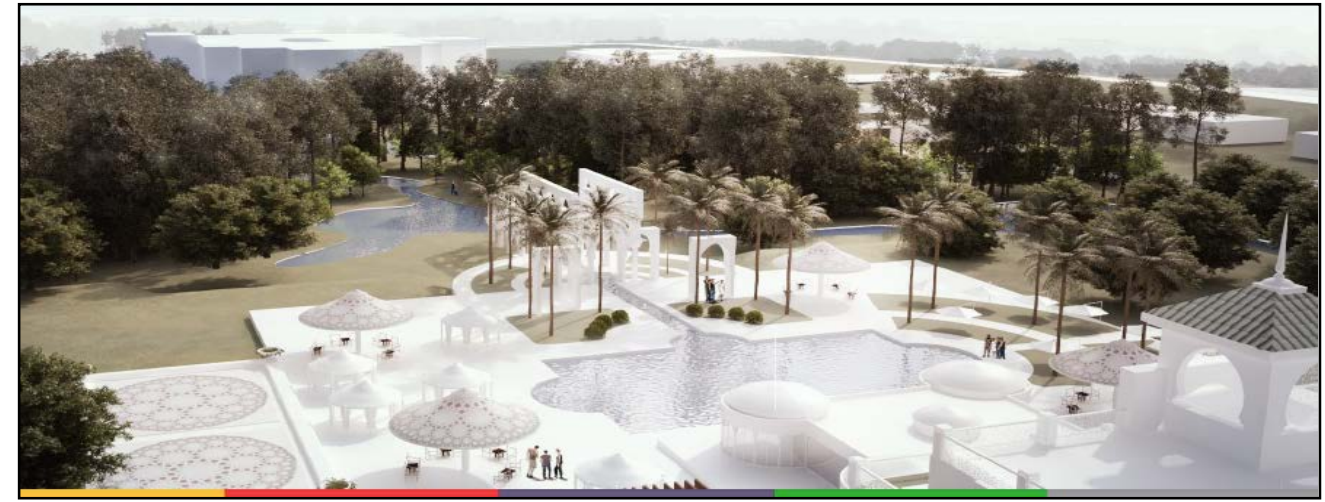

Figure 6b - Cairo, Islamic Pattern of Street Seating Units

\footnotetext{
${ }^{19}$ Marco Manders, "Tulpi-design" http://www.tulpi.nl/tulpi-seat/

${ }^{20}$ Official Governmental Presentation provided from New Capital Company website, http://thecapitalcairo.com/
} 


\subsection{Street Furniture Elements \& Materials and Analysis of New Trends:}

a) Elements: Street Furniture includes numerous elements not limited to billboards, lamp posts, lit signage, phone booths, mailboxes, park seating benches, bike racks, public art, utility poles, traffic signals, information boards, and city maps. Some of these mentioned elements are equipped with cloud-connected devices to make citizens and residents' lives more comfortable.

b) Materials ${ }^{21}$ : The characteristics of material use, stability of the product and the psychological effects it creates are important, for the best design relies on strong, simple and natural shapes and materials. The list of the used material in smart Street Furniture covers the following:

- Steel: It is the most preferred material because it's durable and resistant to rust. It requires little maintenance and relatively cheap compared to other materials.

- Wood: It is one of the most preferable materials for its natural features, but it had a major disadvantage as well. it takes longer to dry after rain and needs more maintenance.

- Concrete: It is durable, difficult to dry after rain and expensive to use.

- Stone: Same as durable and difficult to dry after rain but has only limited designs possibilities.

- Plastic: It is in the smooth surface side, good appearance, more durable, and needs less maintenance.

In New Cairo Administration Capita,' proper considerations have been concluded that Steel will has the priority among other materials but Wood and Concrete will also be used based on the location, the nature of placement and its purposes. The priority of steel is for being a high quality material and its processing technique that will ensure robust Street Furniture ready to face all seasons because its appropriateness for its function, fitting in with environmental constrains and suitability for giving any form.

\section{Street Furniture Design Guidelines:}

General Placement Considerations: Street trees should be the primary organizing element of the streetscape, while Street Furniture should be placed where it can accommodate the majority of the people. Yet, the designer should be mindful of other specific elements; and within the overall pattern of plantings and furnishing. The city's design and general placement considerations should be flexible enough to be able to tailor the size and type of Street Furniture to suit the specific needs of the individual communities.

Specific location guidelines for each element are detailed by element on individual Street Furniture and it's not limited to the following examples:

\section{General Considerations ${ }^{22}$ :}

i. Within the local \& site specific context of streets and parks: avoid placing furniture in front of significant buildings where possible and practical, minimize the impact by placing items to the sides or edges of the building, use benches instead of seats, use bike brackets fixed to existing posts instead of stainless steel bike hoops, clear glass panel bus shelters instead of solid panels.

ii. Within the broader context of streetscape areas and parks: keep the quantity of furniture to the minimum standard required to provide the appropriate level of service, and reduce clutter by rationalizing furniture with new works and consolidating furniture together in clusters.

Specific Consideration ${ }^{23}$ per Item:

- $\quad$ Street lighting: should be located alternately with street trees.

- $\quad$ Park seating benches: should be placed according to design intent; be situated parallel to the pedestrian clear way. For example, when located at a transit stop, they should face the street for functionality, and when intended for rest and people watching, they can be placed so that the pedestrian is encouraged to feel a sense of privacy while still connecting with the public square. It can be placed near popular restaurants to accommodate people waiting to be seated. Seating incorporated into building forms, such as seat-walls, may be used as an alternative to free-standing benches.

- $\quad$ Bike racks: should be located in the buffer zone with a 3 foot minimum clearance between bicycles parked at racks and other Street Furniture.

- $\quad$ All newspapers racks are located in the buffer zone, yet open toward the pedestrian through a way.

\footnotetext{
${ }^{21}$ Ghorab, 2014 , Istanbul, Turkey, "Evaluation of Street Furniture according to basic design principles", Design Principles p.6

${ }^{22}$ CITY OF BALLARAT, Urban Design Manual, "Part A: Street and Park Furniture Guidelines", 2013, street_and-park_furniture_3.pdf $-\mathrm{p} 9$

${ }^{23}$ Donlad Watson, Alan Plattes, Robert Shibley, 2003, "Time-Saver Standards for Urban Design", McGraw-Hill Companies. P 6.5 - 4
} 
- $\quad$ Chairs, tables: are typically located close to the buildings.

- $\quad$ Recycling Bins: Placed in a manner which allows clear sight lines for pedestrians, cyclist, and drivers.

- $\quad$ Other furnishings: should be placed between these organizing elements, clustered at predictable, high-use locations such as transit stops or corners.

c) Analysis of New Trends Samples: We have summarized most of applications of new trends in six trends aiming to be last updated trends; eco-friendly and more comfortable so that urban environment could integrate technology with the communal living. Thus, it gets more tech-oriented and somewhat futuristic as being mentioned in the following sections.

\section{Trend of Multifunctional ICT Devices (Feature \& Usages):}

Smart Stations ${ }^{24}$ for Buses: It is to incorporate with $4 \mathrm{G}$ technology, Wi-Fi connectivity and to support transport providers with an additional source of revenue in terms of digital advertisements by outdoor media companies.

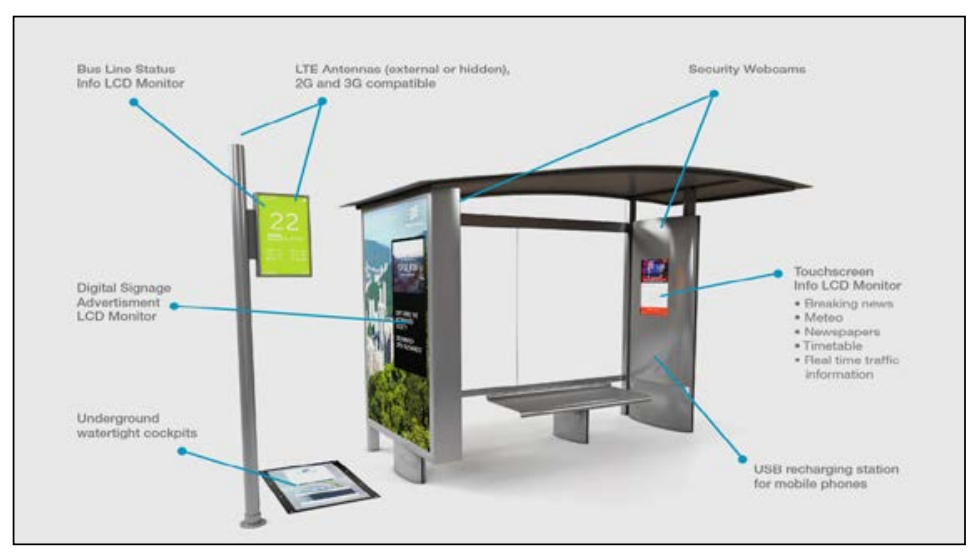

Figure 7 - Smart Bus Station

As shown in Figure 7: The bus station as a cloud device, include screens that display real-time information about bus movements and touch-screens that provide access to interactive maps, local news, tourist information as well as a USB charging port for mobile devices and advertising.

\section{Trend of Responsive Street Furniture Devices ${ }^{25}$ :}

Responsive Street Furniture uses digital technology to make streets work better for people who find moving around difficult for the different types of reasons. It brings the adaptability of digital devices, like iPad, allowing it to be changed to the best that suits the needs of the individuals. These changes include brighter street lighting, audio information, extra places to use and more time to cross the road.

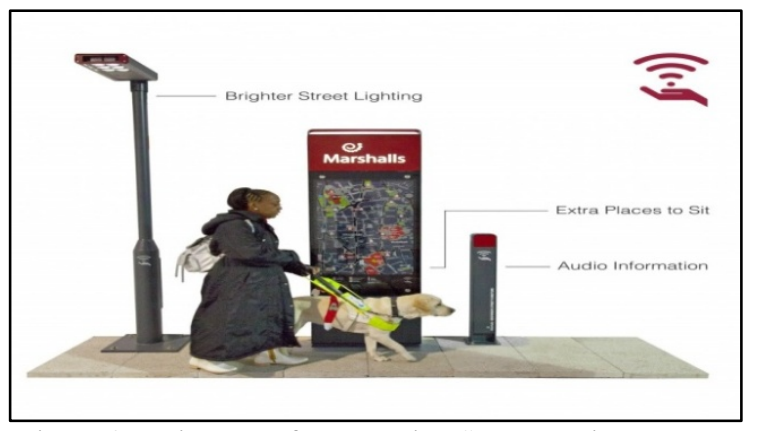

Figure 8 - Diagram of Responsive Street Device

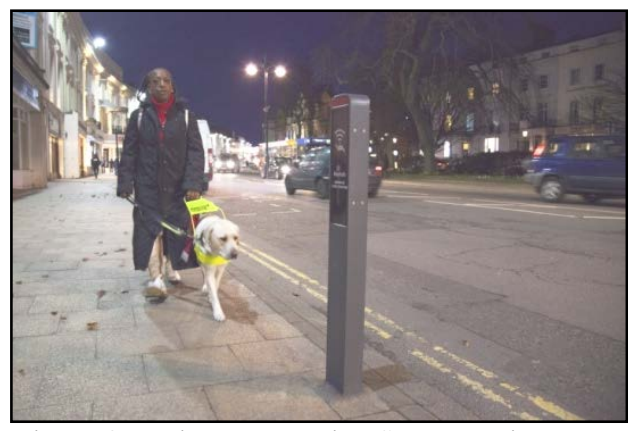

Figure 8a - Live Responsive Street Device

As shown in Figure 8 \& 8a: In contrast, accessibility in the digital world of Smartphone, tablets and websites is all about adaptability. When a device or application can adapt, it can meet the needs of an individual much more completely, rather than trying to be the best compromise between everyone. Prototypes of Street Furniture try to

\footnotetext{
24 Ericsson, in "UITP World Congress", 2015, https://www.ericsson.com/spotlight/services/connected-bus-stop-for-a-better-commuterexperience

$\frac{25}{25}$ Ross Atkin Associates, "Research, design and development", http://www.rossatkin.com/wp/?portfolio=responsive-street-furniture
} 
adapt to disabled people's mobility and offer them a customized experience in real time. After registering with their Smartphone, users can specify their needs while walking on the streets.

\section{Trend of Pop-Up26 (Hydraulic Power Units) Furniture:}

As shown in Figure 9, it portrays a new kind of outdoor furniture that can be pumped out of the pavement by the users. Hydraulic system allows the furniture to be fixed at any height.

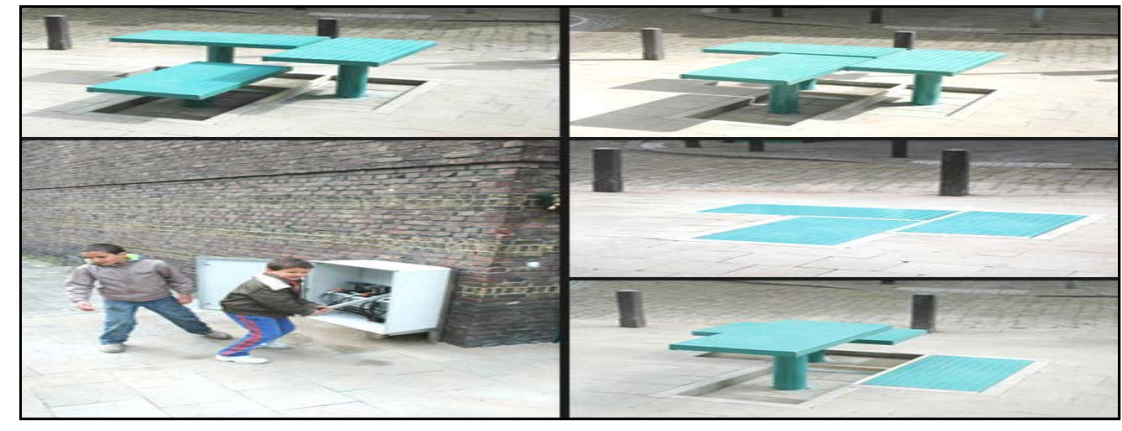

Figure 9 - Example of Hydraulic Power Street Units

This means that you can decide whether you want to create a bench or a picnic table. This furniture folds and disappears into the sidewalk. It is fabulous for public spaces and it creates a great urban design, as (Fig 9).

\section{Trend of Sustainable Technology:}

Optical Technology: Energy Solar LED Street Lamps:

With the increasing energy crisis, countries are seeking to solve the crisis via establishing , for example, a road to seek new and renewable energy use; solar panel reducing energy consumption, or increasing energy efficiency. The LED street lighting is an integrated light-emitting diode (LED) light fixture that is used for street lighting, which can be used for major roads, sub-major roads, and highways. It is highly efficient, long lasting environmentally, friendly and also inherently controllable, (Figs 10-10a)

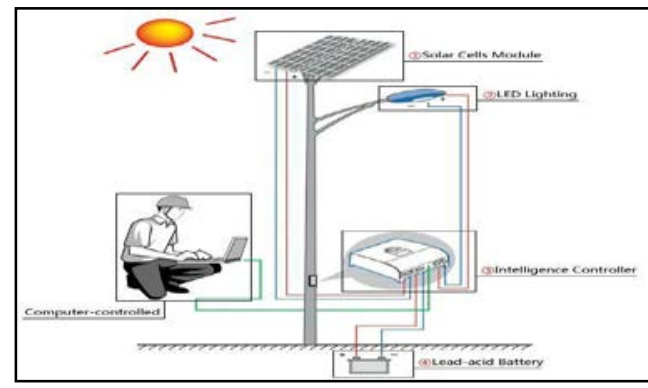

Figure 10 - Diagram of Solar LED Street Lamps

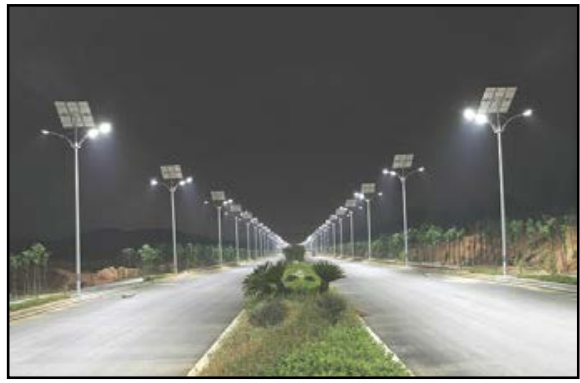

Figure 10a - Live Solar LED Street Lamps

A central control monitoring system that detects whether when they are working or not in order to alarm the responsible technician as shown in the above diagram.

Benefits of Solar LED lights:

Improved community, safer society, and more colorful.

Reduced energy and light pollution.

An even distribution of light to concentrate the light onto the pavement, road and minimize the back spill.

A central control monitoring system that detects whether they are working or not in order to alarm the responsible technician.

Digital Technology: Informative Digital Signage ${ }^{27}$ :

The first Smart Street Solution in the Middle East region has been installed at a high-tech park of Dubai, offering Wi-

\footnotetext{
${ }^{26}$ Popsop Ltd, "Learn 7 trends in urban living for 2014",http://popsop.com/2013/12/what-a-smart-city-of-the-future-will-look-like-learn-7trends-in-urban-living-for-2014/

${ }^{27}$ Emirates 24 News, July 2016, "Region's first smart street unveiled in Dubai", http://www.emirates247.com/news/emirates/region-s-firstsmart-street-unveiled-in-dubai-click-for-where-2016-07-03-1.634798
} 
Fi access and real-time news display besides incorporating sensors monitoring temperature, humidity and air quality installed by Huawei.

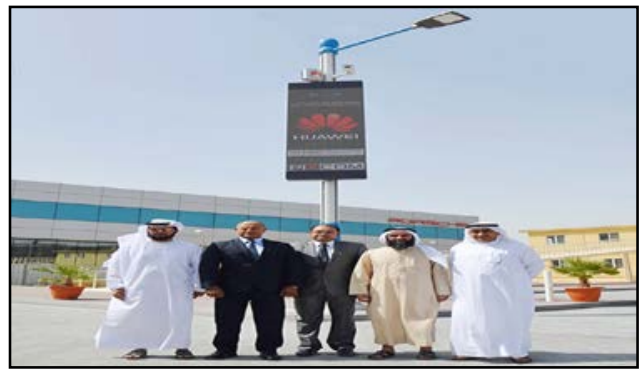

Figure 11 - Dubai, Informative Digital Signage

It allows real-time display of news and information, while the integrated Wi-Fi transmitter offers internet access within a 300 meter radius, as shown in Figure 11

\section{Trend of Virtual Technologies:}

The era of global digitalization, information and big data, is making food shopping better, smarter, more convenient and more interesting. it will enhance public boards at streets as instant displays with products relavent to the customers' interest. These boards are installed in bus stations. Customers scan products codes with their phone, and the groceries are delivered to their homes.

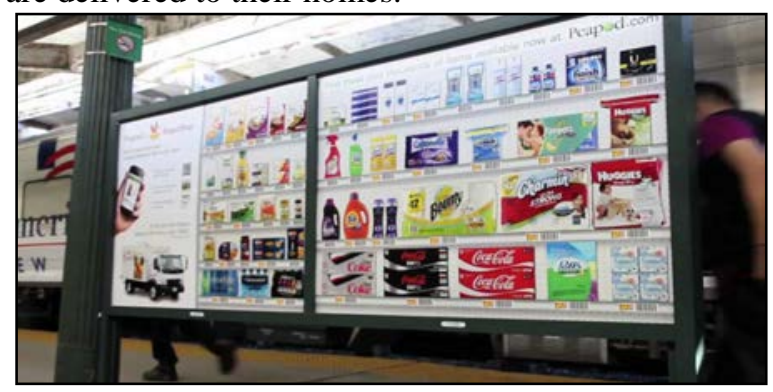

Figure 12 - Virtual Shopping Channel

As shown in Figure 12, It is an innovative shopping channel for shoppers to virtually interact with their chosen stores or products. That will offer customers an immersive purchasing experience, allowing endusers to digitally interact with stores and explore products in an innovative 3D enabled format.

\section{Trend of Modular Street Furniture ${ }^{28}$ :}

The core aim is to empower landscape architects and specifies it with the freedom to create something unique for each and every project. It is also to match the palette of the surrounding environment without the associated costs of any off bespoke products.

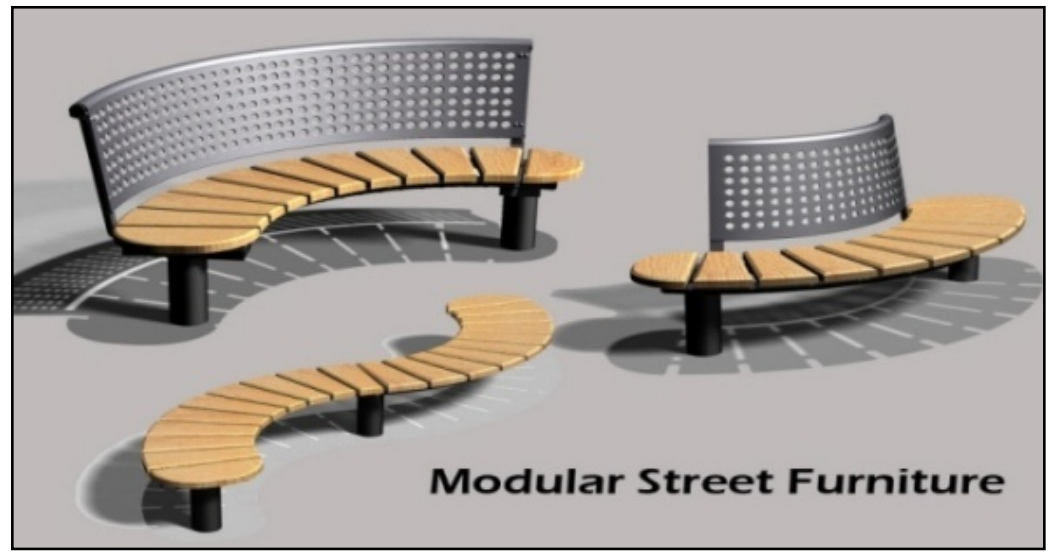

Figure 13 - Modular Street Furniture

\footnotetext{
${ }^{28}$ Rachel Pownall, "Modular Street Furniture", 2008, http://www.coroflot.com/rachel_pownall/modular-street-furniture
} 
As shown in Figure 13, The benches ${ }^{29}$ are a mixture of internal and external curves to create different configurations, either allowing people to sit alone or together- encouraging social interaction.

\section{Conceptual Planning Model (CPM) for Street Furniture:}

Conceptual modeling ${ }^{30}$ in general is the activity of formally describing some aspects of the physical and social world around us for the purposes of understanding and communication.

A conceptual model's primary objective is to convey the fundamental principles and basic functionality of the system which it represents. Also, a conceptual model must be developed in such a way as to provide an easily understood system interpretation for the users.

\section{A conceptual planning model, when implemented properly, should satisfy four fundamental objectives:}

1. Enhance the individual's understanding of the representative system.

2. Facilitate efficient conveyance of system details between all parties involved.

3. Provide a point of reference for system designers to extract system specifications.

4. Document the system for future reference and provide a means for collaboration.

Proposed conceptual planning model - CPM for Smart City and Street Furniture as direct implementation of Smart City's identity to be applied within our case study of "New Cairo Administration Capital" plays an important role in the overall planning and designing process. It is clear that if the conceptual model is not fully developed, the execution of fundamental system properties may not be implemented properly, giving way to future problems or system shortfalls. These failures do occur in the industry and have been linked to; the lack of user input, the incomplete or unclear requirements, and the changing requirements.

The expected outcome is to have an overall enhancement for designing new ideas and trends to be used in the designing and manufacturing of the Street Furniture's materials. It is an ideal criterion for designers as a general guide for making a scientific curriculum to be updated with what's new using Hi-Tec communications, worldwide.

\footnotetext{
29 Andrew H. Dent \& Leslie, "Material Innovation Architecture", 2014, UK in Thames \& Hudson Ltd. P 104-105

${ }^{30}$ Wikipedia, 'Conceptual Model", https://en.wikipedia.org/wiki/Conceptual_model
} 


\section{Conceptual Planning Model -CPM:}

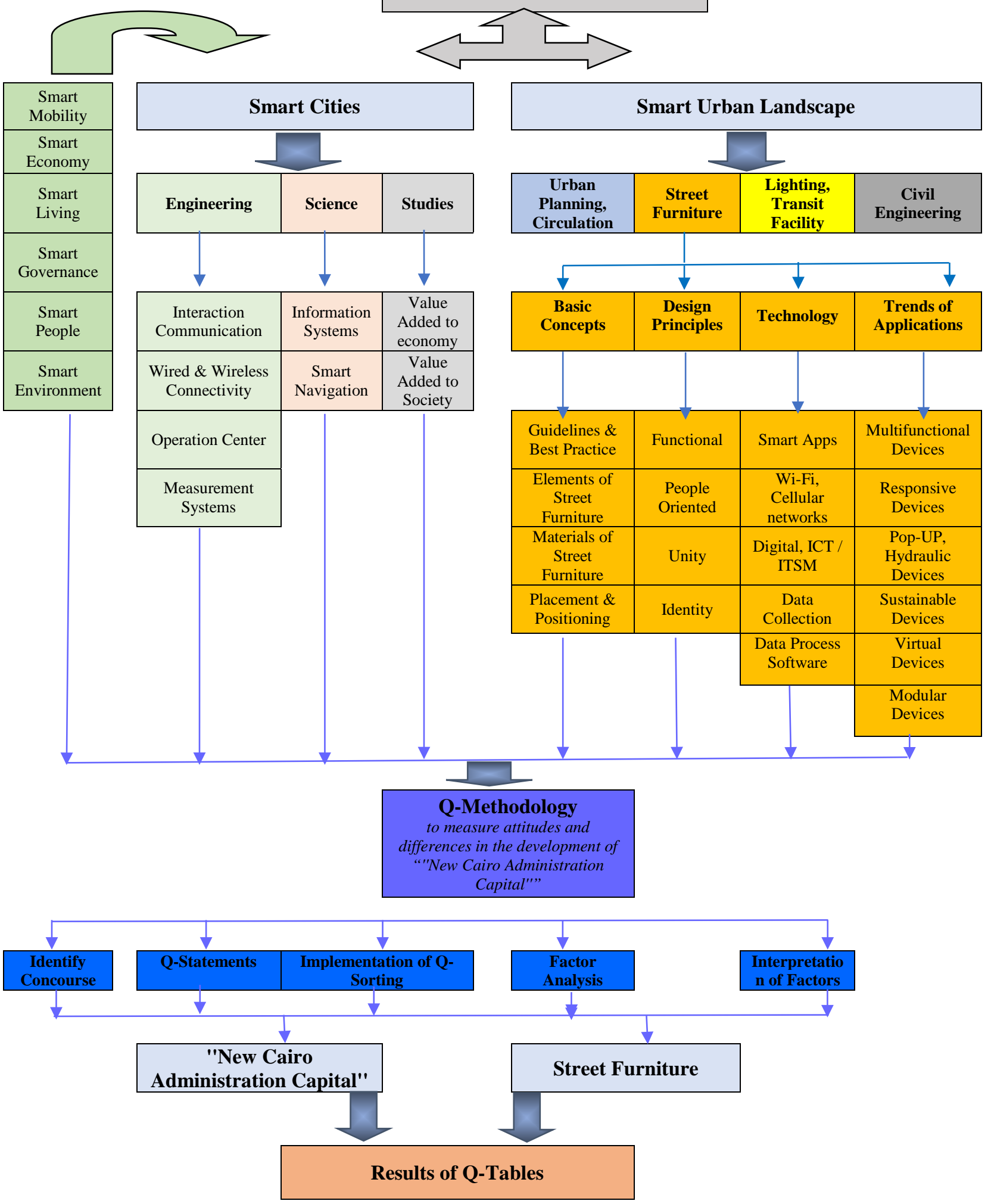


Figure 14 - Conceptual Planning Model -CPM

\section{Findings, Conclusion and} Recommendations

As indicated above - in Figure 14, we will start implementing the above planned processes for each topic individually. First, for the "New Cairo Administration Capital" as a Smart City, then last but not least, our core topic of Street Furniture:

\section{3 "New Cairo Administration Capital":}

"New Cairo Administration Capital” ${ }^{31}$ is a large-scale project announced by the Housing Minister- Mustafa Madbouly on the $13^{\text {th }}$ of March 2015. As a Smart City located in 45 kilometers east and just outside the Second Greater Cairo Ring Road, it would become the new administrative capital, housing the main government departments, ministries, as well as foreign embassies. On 700 square kilometers total area, a population of 5-7 million people is expected to live and grow, Figure 15.

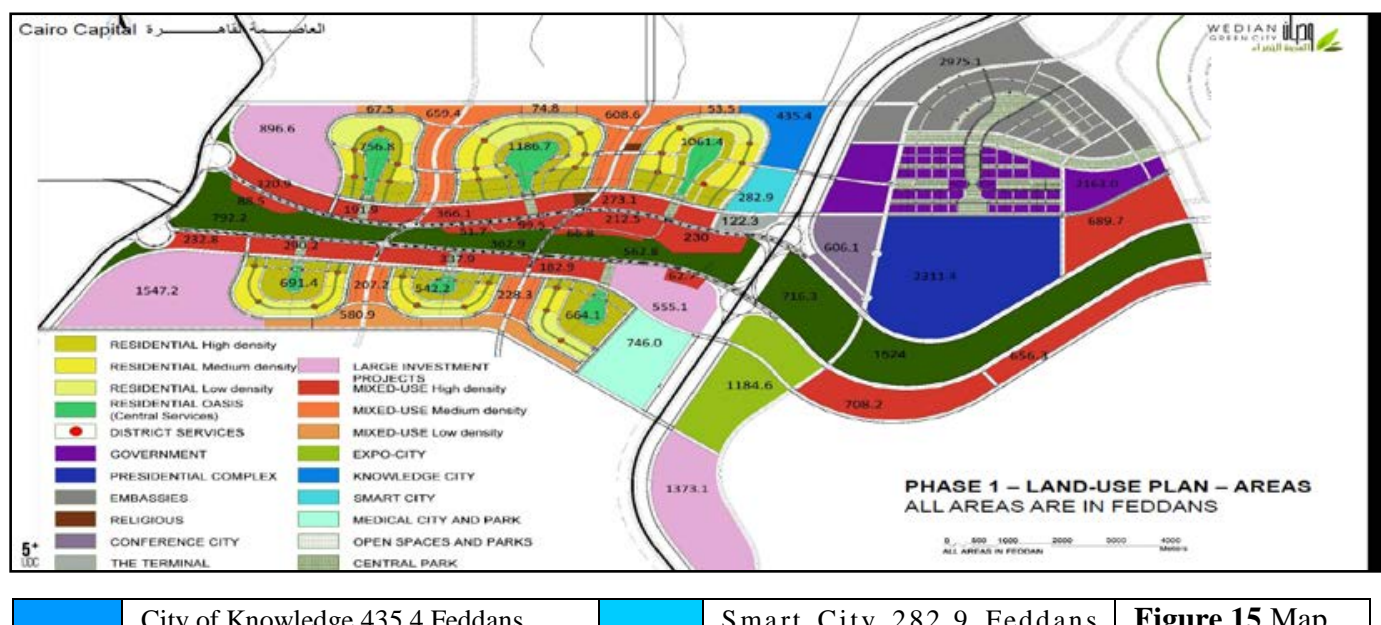

"New Cairo Administration Capital" is planned to be consisted of 21 residential districts and 25 "dedicated districts". Its downtown is to have skyscrapers, Figure 15a. The city will also have a central park, artificial lakes, about 2,000 educational institutions, a technology and Innovation Park, 663 hospitals and clinics, 40,000 hotel rooms, 90 square kilometers of solar energy farms, an electric railway and a new international airport. The city is designed in 282.9 Feddans (Figure 15a) and the City of Knowledge is to be in the size of 435.4 Feddans, (Figure 15b) as follows:

\section{Smart City, Downtown, Skycrapers \& Central Park:}

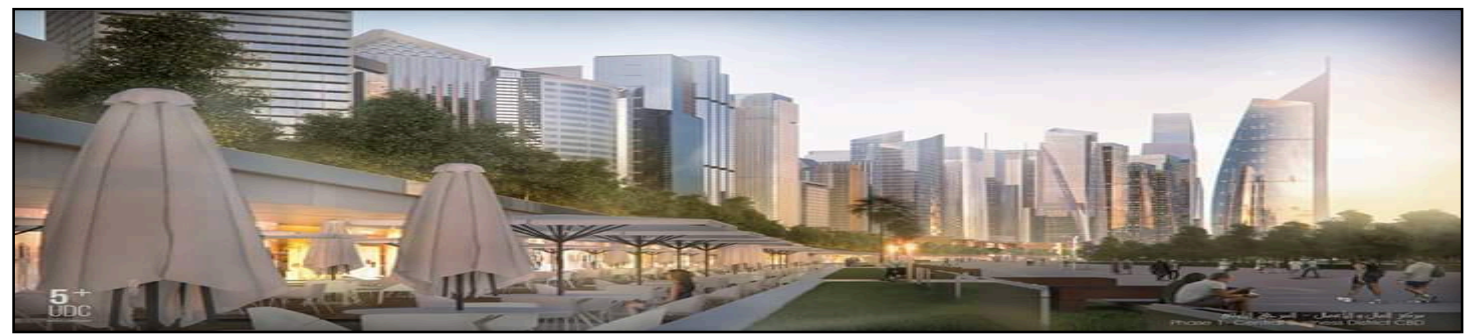

Figure 15a - Layout of Downtown, Skyscrapers \& Part

City of Knowledge - Plan for Land Use of 417 Feddans:

\footnotetext{
${ }^{31}$ Wikipedia, "Proposed New Capital", https://en.wikipedia.org/wiki/Proposed_new_capital_of_Egypt
} 


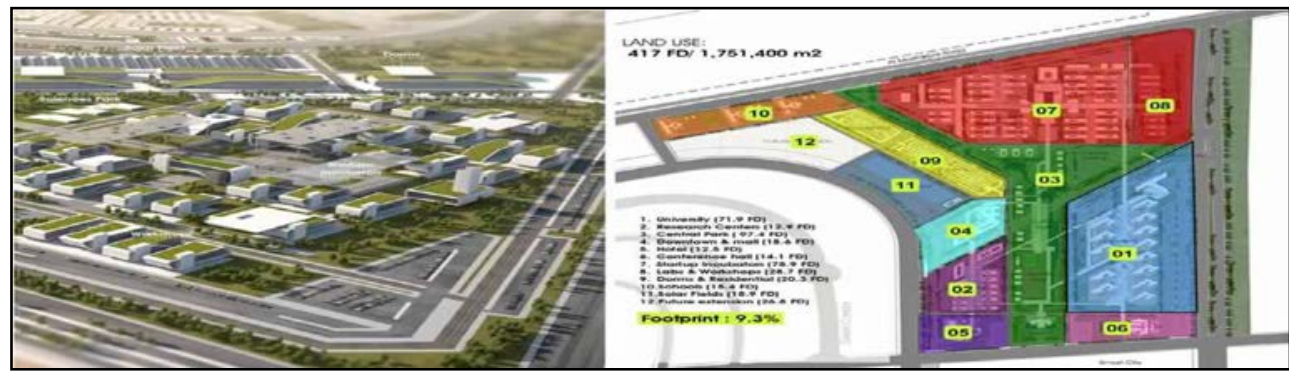

Figure 15b - Detail Plan for City of Knowledge

\subsubsection{Success Factors for Planning New Cairo City:}

- Initially, Cairo Capital Company is the in charge company establishing, constructing, and manageing the new city talked to municipal economic development officials under the authority of Cairo Governate. It is to explain the opportunities, requirements, and benefits associated with wireless Street Furniture and seek support from the Ministry of Communication and Information Technology, MCIT, as well as Information Technology Industry Development Agency, ITIDA for most updated common practice technology within the region. This process has been finalized in less time than what was planned for.

- Secondly, The Company identifies all special local considerations of historic districts, architectural and requirements that may increase costs /or extend the timeline of the deployment process. It has been concluded to have the design based on Islamic pattern to create a great impact on its identity.

The following planning and live-pictures (i.e. under construction) as Figure 16, showing implementation of the Islamic Identity in all residential buildings:

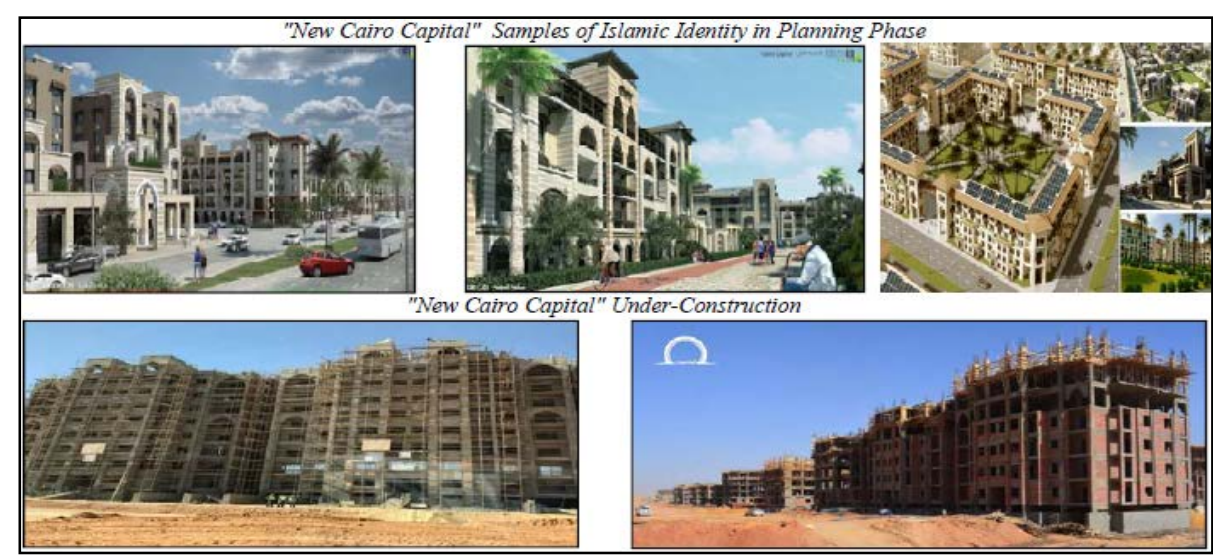

Figure 16 - Constructions in Progress \& General Layouts

Then, coordinating legal franchising and other permitting governmental requirements to identify timing and other expectations from both municipal bodies and infrastructure provider perspectives (i.e. subcontracting companies such as Arab Contractors Co., Orascom Constructions Industries - OCI, etc..) to plan for the whole execution project plan which concludes that its first phase is subject to finalization within 2018.

- Third, realistically discuss estimate costs for the access in relation to any published municipal schedule or point of view. The nature of the project seeks interpretations as needed for the project's economic viability including commercial and economic feasibility studies.

- Finally, prepared to respond promptly to standard code of construction and safe infrastructure based on best common practice used within similar Smart Cities in the region.

\subsubsection{Main Aspects of Planning 32:}

The vision of technology elements ${ }^{33}$ and its priority as best practices in design are as follows:

\footnotetext{
32 The Capital Cairo, http://thecapitalcairo.com/smart-city.html

33 TNT News, India, 2016, "Tag Archives: Smart City", TNT, thenortheasttoday, http://thenortheasttoday.com/tag/smart-city/
} 


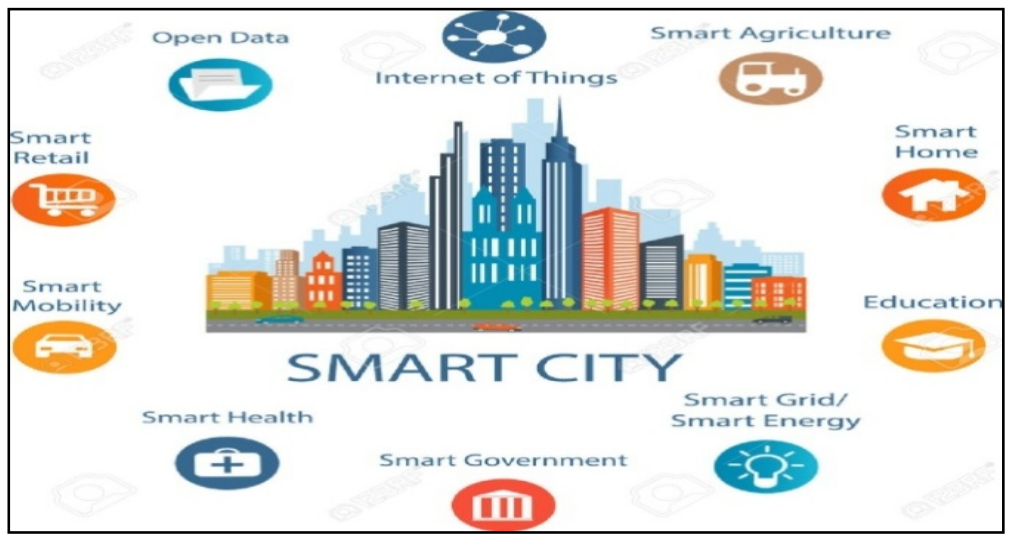

Figure 17 - Features Elements of Smart Cities

\section{As shown above Figure 17:}

- Technology Elements: Urban automation, connected devices and intelligent or senor-based infrastructure which present the highest priority in the planning phase.

\section{- Smart City Elements:}

contains open data \& internet, smart agriculture, smart home \& retail, smart health \& education, smart grid \& energy, smart e-government, and smart mobility having all together priority in planning.

\section{- Innovation Approaches to Transportation Elements ${ }^{34}$ :}

Urban Analytics; user- urban delivery and logistics; strategic business models, roadway electrification, and electric vehicles, that are connected and involved citizens having high priority.

There are three core factors that will properly be considered in "New Cairo Administration Capital” as following: a.From Technology Perspectives:

Physical infrastructure; smart; mobile; virtual technologies, and digital networks:

- Protected and organic waste recycled in order to grow.

- Well-connected locally, regionally and internationally.

- Make use of the sustainable technologies of today.

- Infrastructure will be able to make, reuse and conserve water and waste.

- 90 square kilometers of solar energy farms.

b. From Human Perspectives:

Human infrastructure; social capital:

- $\quad$ Variety of medium and high-density districts to address the issues of land constraints and population density.

- Exceptional quality of life with compact walkable urban neighborhoods, lush green gardens (i.e. Green

River) and shaded walkways to ensure a sense of community.

- Electric railway and new international airport

- Focus will be on promoting pedestrian-friendly choices throughout the city.

c.From Institutional Perspectives:

Policy; regulations and directives as follows:

- All governmental bodies and ministries will be re-located in "New Cairo Administration Capital"

- Educational institutions, a technology \& innovation park "i.e. City of Knowledge", hospitals, clinics, and international hotels, etc.

\subsubsection{Q-Methodology Approach in planning \& designing "New Cairo Administration Capital":}

Q-methodology ${ }^{35}$ was originally invented by psychologist, Stephenson, in 1935 in order to examine individuals' subjectivity systematically and scientifically, and then this research method has been developed further based on factor analytic theory. This methodology is recognized as an evaluation tool combining both qualitative and quantitative research techniques.

The research uses this method to measure attitudes and different in the development of "New Cairo Administration Capital" based on the particular standing point of the observed participations. This subjective landscape on Smart Cities and Street Furniture can be valuable to understand the exiting debates in practice and

\footnotetext{
34 New Jersey Department of Transportation, 2008, USA, Pennsylvania Department of Transportation

35 Dr. Joon Sik Kim, Xi'an Jiaotong - Liverpool University, Mapping Conflicts in the Development of Smart Cities: the Experience of Using Q Methodology for Smart, Gusu Project, Suzhou, China, 2016, CORP2016_13.pdf, pages. 1-10
} 
implement projects more efficiently by mapping possible conflicts in advance. This method employs quantitative tool of factor analysis in the following five main stages:

1. Identification of the "concourse":

At this stage, it is to develop a wide range of discussion, and questions in order to collect the concourse.

2. Definition of Q-Statements:

The discourse collected from the above stage needs to be summarized and reduced to a manageable number of the concourse, which is often referred to as Q-Statements.

3. Implementation of Q-sorting:

This stage involves the interview process with selected participants to ask rank all Q-statements on a scale from "disagree level (-4)" to "agree level (+4)". The range, such as down (-4) to high (+4) will be used to sort the statements in the later stages.

4. Factor Analysis:

When Q-sorting is completed, the correlations between Q-sorts are calculated by using the factor analysis method. This statistical analysis is to identify and classify a distinctive group of Q-sorts that shares a similar subjective opinion or position received from the participants.

5. Interpretation of the Factors:

Final stage is to interpret the results of the factor analysis based on the findings.

Implementation of Q-Methodology \& Work Done:

1. "Concourse": We have selected number of key governmental officials as well as from non-government companies based on their background, work and experience that can provide assurance to our findings, enhancing particular support to answering our questions. Firstly, open discussions have been implemented to acquire basic information and current issues of "New Capital" from media such as newspapers, websites, government documents, etc. Secondly, meetings and phone conversations have been concluded with five key professional experts, of three from government officials; and two operational and scientific officials whom working at non-government sector.

2. "Q-Statements": The typical number of Q-Statements to be in 30 and 60. Drawn from initial tests and pilot Q-Sorting, the research has found 50 statements / questions as factual-statements covering Smart City and its related Street Furniture which will be considering during planning, designing and implementation processes of ""New Cairo Administration Capital"” and are suitable for this study.

3. "Q-Sorting": All Q-Statements were given one by one randomly to the participant, then to split them up into categories: disagree; agree and neutral based on their own perspectives. Then, the participant is required to place all statements into the Q-table in a ranked-order according to the forced distribution. At the last stage of Q-sorting, the participants are required to complete a questionnaire for their personal details. Participants were asked to use an inverted pyramidal table (Figs 18 \& 19) in order to rank the 50 Qstatements in a nine-relative (9) nine scale $(-4,-3,-2,-1,0,+1,+2,+3,+4)$ based on how strongly they agree or disagree with or against each particular Q-Statement.

4. "Factor Analysis": We have two main segments for the questionnaire, first for Smart Cities surveyed in 23 Q-statements; and secondly, Street Furniture surveyed in 27 Q-statements (TOTAL OF 50). Unified factors of 0.33 and 0.22 is unfind for both of the governmental for the non-government that have been calculated to measure the level of acceptance.

\section{Q-Methodology Approach:}

There are many designing approaches, types of elements, materials to use, placement principles, functionality and appearance features for Smart City and Street Furniture that differs from city/or region to another. All these Q-statements were submitted, or discussed, and interviewed with 3 key government perspectives; and 2 nongovernment perspectives. The following inquires; questions and factual statements have been prepared and answered by selective key professional experts (i.e. Participants) as listed herewith:

\section{Key Government Perspectives:}

\begin{tabular}{|c|l|l|}
\hline a & Mr. Wael Mousa & Assistant to Ministry of Housing, Utilities and Urban Development, \\
\hline b & Dr. Ahmed Farouk & Ministry Advisor for National Projects - Ministry of Investment, \\
\hline c & Eng. Mohamed Arab & Advisor to the National Regulatory Authority Telecommunications \\
\hline
\end{tabular}

\section{Non-Government Perspectives:}

\begin{tabular}{|c|l|l|}
\hline d & Eng. Safwat Sobhy & CEO, Orascom for Construction Industries, OCI \\
\hline e & Dr. Ayman Ashour & Dean of Faculty of Engineering, Ein Shams University \\
\hline
\end{tabular}




\section{i. "New Cairo Administration Capital" as a Smart City:}

The interview participants to ask are ranking all Q-Statements on a scale from "disagree (-4)" to "agree (+4)"

\begin{tabular}{|c|c|c|c|c|c|c|c|}
\hline \multicolumn{8}{|c|}{ Participants } \\
\hline $\begin{array}{l}\text { Topic of } \\
\text { Statement }\end{array}$ & No. & Q-Statements & $\mathbf{a}$ & $\mathbf{b}$ & C & d & $\mathbf{e}$ \\
\hline \multirow[t]{2}{*}{$\begin{array}{l}\text { Aspects of } \\
\text { Planning \& } \\
\text { Design }\end{array}$} & 1 & $\begin{array}{l}\text { Planning process is based on best practices in design, } \\
\text { ecology and culture, common Smart City components and } \\
\text { innovation approaches for whole city and especially for } \\
\text { urban pillars of ease accessibility for transportation and } \\
\text { circulation movements are properly considered. }\end{array}$ & +4 & +4 & +4 & +4 & +4 \\
\hline & 2 & $\begin{array}{l}\text { A Smart City is one with at least one initiative of the } \\
\text { following six characteristics: smart governance, people, } \\
\text { living, mobility, economy and smart environment. "New } \\
\text { Cairo Administration Capital" is planned base on } \\
\text { implementing most of these main characteristics as } \\
\text { smartness feature. }\end{array}$ & +4 & 3 & +4 & 3 & -3 \\
\hline $\begin{array}{l}\text { Topic of } \\
\text { Statement }\end{array}$ & No. & Q-Statements & $\mathbf{a}$ & $\mathbf{b}$ & c & d & $\mathbf{e}$ \\
\hline $\begin{array}{l}\text { Aspects of } \\
\text { Planning \& } \\
\text { Design }\end{array}$ & 3 & $\begin{array}{l}\text { A Smart City around the world have three different views, } \\
\text { first is Smart Cities as "Engineering", secondly, is mart } \\
\text { cities as "Science" and last but not least is Smart Cities as } \\
\text { "Studies", all these views are properly considered. }\end{array}$ & +4 & 3 & +4 & +4 & 3 \\
\hline \multirow[t]{2}{*}{$\begin{array}{l}\text { Technical } \\
\text { Consideration }\end{array}$} & 4 & $\begin{array}{l}\text { Infrastructure designed is able to make, reuse and conserve } \\
\text { water efficiently, protected and organic waste recycled, as } \\
\text { well as effective-connected and open data, internet, GSM } \\
\text { technologies (i.e. G-4) for communication with deep } \\
\text { involvement of solar energy as prime source for power and } \\
\text { as green environment main requirement. }\end{array}$ & +4 & +4 & +4 & +4 & +4 \\
\hline & 5 & $\begin{array}{l}\text { For the image of smart capital will use as much as } \\
\text { Information Communication Technologies - ICT as well as } \\
\text { multi-users devices that save time, efforts in an effective } \\
\text { and efficient manner as well. }\end{array}$ & +4 & 3 & +4 & +4 & 3 \\
\hline $\begin{array}{l}\text { People \& } \\
\text { Public } \\
\text { Services }\end{array}$ & 6 & $\begin{array}{l}\text { Information sharing between governments and enterprises } \\
\text { would be an asset in building the information system via } \\
\text { e-government that will provide citizen-centric services with } \\
\text { efficient administrative procedures. }\end{array}$ & +4 & +4 & +4 & 3 & 3 \\
\hline \multirow[t]{2}{*}{$\begin{array}{l}\text { Public \& } \\
\text { Private } \\
\text { Buildings }\end{array}$} & 7 & $\begin{array}{l}\text { Government is in need for modern building management } \\
\text { systems to organize effective repairs works, maintenance } \\
\text { more effectively and efficiency for sustainability proposes. }\end{array}$ & +4 & +4 & 3 & +4 & +4 \\
\hline & 8 & $\begin{array}{l}\text { All residents building will have sort of intelligent systems } \\
\text { and smart services to improve living environments }\end{array}$ & 2 & 3 & 3 & 3 & 2 \\
\hline \multirow[t]{2}{*}{$\begin{array}{l}\text { Economy \& } \\
\text { Positive Value } \\
\text { Added }\end{array}$} & 9 & $\begin{array}{l}\text { Green energy solutions (i.e. solar) are becoming basic goal } \\
\text { for the development of "New Cairo Administration Capital" } \\
\text { that will saving cost and achieving green environment as } \\
\text { planned. }\end{array}$ & +4 & -3 & +4 & +4 & +4 \\
\hline & 10 & $\begin{array}{l}\text { "New Cairo Administration Capital" is not just about } \\
\text { implementing technology for the sake of technology but } \\
\text { rather, follow an informed agenda to combat various urban } \\
\text { challenges in Egypt, such as growing populations and } \\
\text { issues relating to basic service delivery, and social } \\
\text { inclusion. So, all these constrains have been accounted for } \\
\text { within the planning. }\end{array}$ & +4 & +4 & +4 & +4 & 3 \\
\hline \multirow[t]{2}{*}{$\begin{array}{l}\text { Characteristics } \\
\text { of Smart } \\
\text { Cities }\end{array}$} & 11 & $\begin{array}{l}\text { The following prioritized characteristics for planning Smart } \\
\text { Cities have been considered in the case study: } \\
\text { - Wired and wireless connectivity }\end{array}$ & +4 & 3 & +4 & 3 & 3 \\
\hline & 12 & - Effective information systems & 3 & 3 & +4 & 3 & +4 \\
\hline
\end{tabular}




\begin{tabular}{|c|c|c|c|c|c|c|c|}
\hline & 13 & - Commuter information model, mobile payment, & +4 & +4 & 3 & 3 & +4 \\
\hline 14 & $\begin{array}{l}- \text { Operation center to operate, maintain, and control all } \\
\text { activities within the capital }\end{array}$ & 3 & 2 & 2 & 3 & 2 \\
\hline 15 & - Air pollution counter-measures, & +4 & 3 & 3 & 2 & 3 \\
\hline 16 & - Smart water utility pipe leak, irrigation, waste systems & +4 & 3 & +4 & 3 & -3 \\
\hline 17 & - Real time 3D maps, & 3 & 2 & -3 & 2 & -3 \\
\hline 18 & $\begin{array}{r}- \\
\text { Efficient public transport, stimulating green behavior, } \\
\text { smart buildings }\end{array}$ & 3 & 3 & +4 & 3 & 3 \\
\hline 20 & $-\begin{array}{l}\text { Smart running, bikes tracks and elderly care systems } \\
21\end{array}$ & -2 & 3 & 2 & 3 & 2 \\
\hline 22 & $\begin{array}{l}\text { Public parking space availability prediction and } \\
\text { interactive street sensing. }\end{array}$ & +4 & +4 & 3 & 3 & 3 \\
\hline 23 & $\begin{array}{l}\text { Managing household waste, improving cycling safety } \\
\text { and sudden emergencies. }\end{array}$ & 3 & 3 & -2 & 3 \\
\hline
\end{tabular}

Interpretation of the Factors - Q-Table for "New Cairo Administration Capital" as a Smart City:

Results based on calculated factors revealed the following findings: totally agree / or full consent statements (i.e. +4 ) for the two segments are $43 \%$. The agreed opinions (i.e. $+3 \&+2$ ) are $47 \%$. Last but not least, perspectives less than agreeing ( $-3 \&-2$ ranks) is of $5 \%$ as shown in the below inverted pyramidal Q-Table:

\begin{tabular}{|c|c|c|c|c|c|c|c|c|c|c|c|c|} 
FULL DISAGREE & \multicolumn{3}{c}{ SOUND \& LESS DISAGREE } & \multicolumn{1}{c}{ SOUND \& LESS AGREEE } & FULL AGREE \\
\begin{tabular}{|c|c|c|c|c|c|c|c|c|c|c|c|}
\hline Segments / Scale & $-\mathbf{4}$ & $\mathbf{- 3}$ & $\mathbf{- 2}$ & $\mathbf{- 1}$ & $\mathbf{0}$ & $\mathbf{+ 1}$ & $+\mathbf{2}$ & $+\mathbf{3}$ & $+\mathbf{4}$ & Total & Factor \\
\hline Government Perspectives & 0 & 2 & 1 & 0 & 0 & 0 & 6 & 23 & 34 & $\mathbf{6 9}$ & $\mathbf{0 . 3 3}$ \\
\hline Non-Government Perspectives & 0 & 3 & 0 & 0 & 0 & 0 & 5 & 20 & 15 & $\mathbf{4 6}$ & $\mathbf{0 . 2 2}$ \\
\hline & & & & & & & & & & & \\
\hline Pyramidal Q-Table (Fig 18) & & & & & & & & & & & \\
\hline
\end{tabular}
\end{tabular}

As shown in Figure 18, Using the Excel statistical as simple sample tool analysis, the data for "New Cairo Administration Capital" segment were analyzed using the relevant basic statistical processes (i.e. concluded factors of 0.33 \& 0.22 for segments of Governmental and Non-Governmental officers respectively), all relationships between the data were also analyzed; and with the information obtained from the questionnaires built based on Q-Statements conclude that concept, factors, elements of "New Cairo Administration Capital" is been considered within the planning phase and our field visits that all what have been planned for is being implementing during current stage of constructions that schedule phase- 1 will be concluded by midyear of 2018 .

\section{Analysis of Smart Cities Results:}

Total Q-statements for Smart Cities segment are based on 23 statements delivered, discussed and obtained its perspectives from the participants, having a total of 207 ranges of expected responds (9 ranks). Responds received from key government perspectives were more positive than those from non-government due to their more access possibilities to planning and designs of "New Cairo Administration Capital" data and information, whilst others may not be able to have the same amount of detailed data and in-depth information especially during the planning phase.

\section{Thus, positive consents and agreed upon opinions were aggregated and concluded major topics related to} the following:

- Implementation of e-government.

- Building management systems designed based on last technology.

- Application of Information Communication Technology - ICT.

- Solid combat various challenges (i.e. growing population, service delivery, safety).

- Green energy solutions more efficient in operation, maintenance and saving costs. 
Whilst other answers far / away from full consent and agreement opinions concluded major topics related the follows:

- Residents building will not fully intelligent for all smart services, but that will based on type of location providing this requirement of Hi-Tec systems for intended usages.

- All effective information, digital smart systems will be placed in specific areas of interest based on the planning design not deployed over all locations (i.e. main Smart City, city of knoweldge).

- Managing household waste, improving cycling safety are assessed but not in a defiant manner (i.e. not yet planned for).

- Public parking space availability prediction, smart car parking and interactive street sensing are not concluded and planned for yet, but are within the overall consideration list of interests.

\section{ii. Street Furniture in "New Cairo Administration Capital":}

The interview participants to ask are ranking all Q-Statements on a scale from "disagree (-4)" to "agree (+4)"

\begin{tabular}{|c|c|c|c|c|c|c|c|}
\hline \multicolumn{8}{|c|}{ Participants } \\
\hline $\begin{array}{l}\text { Topic of } \\
\text { Statement }\end{array}$ & No. & Q-Statements & $\mathbf{a}$ & $\mathbf{b}$ & c & d & $\mathbf{e}$ \\
\hline Identity & 1 & $\begin{array}{l}\text { Street Furniture has planned in the modern nature, shape, } \\
\text { form in Islamic historical from identity point of view } \\
\text { referring to history of Egypt aiming to enhance its } \\
\text { identity in form of attractive, unity, and unique in nature }\end{array}$ & +4 & +4 & 3 & +4 & 3 \\
\hline $\begin{array}{l}\text { Designing \& } \\
\text { Planning }\end{array}$ & 2 & $\begin{array}{l}\text { Street Furniture is designed, planned and equipped based } \\
\text { on last updated technology in the field (i.e. smart kiosks, } \\
\text { multiuse's devices, etc.) to comply with the smartness. }\end{array}$ & +4 & +4 & +4 & 3 & 3 \\
\hline $\begin{array}{l}\text { Topic of } \\
\text { Statement }\end{array}$ & No. & Q-Statements & $\mathbf{a}$ & $\mathbf{b}$ & c & d & $\mathbf{e}$ \\
\hline \multirow[t]{7}{*}{$\begin{array}{l}\text { Designing \& } \\
\text { Planning }\end{array}$} & 3 & $\begin{array}{l}\text { The planning will integrate technology into Street } \\
\text { Furniture to provide both phone-charging stations and } \\
\text { tools for gathering valuable data as a basic example. }\end{array}$ & +4 & +4 & 3 & 3 & 3 \\
\hline & 3 & $\begin{array}{l}\text { The planning will integrate technology into Street } \\
\text { Furniture to provide both phone-charging stations and } \\
\text { tools for gathering valuable data as a basic example. }\end{array}$ & +4 & +4 & 3 & 3 & 3 \\
\hline & 4 & $\begin{array}{l}\text { Street Furniture elements will uses ICT technology, } \\
\text { connected to Wi-Fi, Hi-Tec devices, exchange of data } \\
\text { and information, all of these are properly considered for } \\
\text { availability of backhaul and power, location of sites to } \\
\text { improving coverage, suitable equipment with available } \\
\text { recently frequency bands of } 4 \mathrm{G} \text { applied in Egypt. }\end{array}$ & +4 & +4 & +4 & 3 & 3 \\
\hline & 5 & $\begin{array}{l}\text { Technical trends of designing Street Furniture worldwide } \\
\text { are as following, kindly indicate which one or more will } \\
\text { be applicable and which will not applicable in } \\
\text { implementation of "New Cairo Administration Capital" } \\
\text { as a smart: } \\
\text { - Trend of multifunctional street units. }\end{array}$ & +4 & +4 & +4 & 3 & 3 \\
\hline & 6 & - $\quad$ Trend of responsive Street Furniture devices. & -4 & -4 & -4 & -4 & -4 \\
\hline & 7 & $\begin{array}{l}\text { - Trend of sustainable applications such as: energy solar } \\
\text { LED; and digital technology such as informative } \\
\text { digital signage. }\end{array}$ & +4 & +4 & +4 & +4 & +4 \\
\hline & 8 & - Trend of modular Street Furniture. & -4 & -4 & -3 & -3 & -3 \\
\hline \multirow{3}{*}{$\begin{array}{l}\text { Functional \& } \\
\text { Technical } \\
\text { Features }\end{array}$} & 9 & $\begin{array}{l}\text { Street will be planned and designed among a wide width } \\
\text { of at least } 90 \text { and max of } 125 \text { meters as standard norms }\end{array}$ & +4 & +4 & +4 & 3 & +4 \\
\hline & 10 & $\begin{array}{l}\text { The common lists of material used in Street Furniture are } \\
\text { Steel, wood, concrete, stone and plastic. The planning is } \\
\text { focusing mainly on Steel, for its sustainability durable, } \\
\text { resistant to rust as well as others (i.e. Wood \& Concrete). }\end{array}$ & +4 & +4 & +4 & +4 & +4 \\
\hline & 11 & For traffic systems in all streets are equipped by & +4 & +4 & +4 & +4 & +4 \\
\hline
\end{tabular}




\begin{tabular}{|c|c|c|c|c|c|c|c|}
\hline & & multifunctional digital display as last technology used. & & & & & \\
\hline & 12 & $\begin{array}{l}\text { Are there are many green parks, spaces and landscape } \\
\text { were accounted for within the planning to allows a } \\
\text { variety of seating furniture for visitors and pedestrians. }\end{array}$ & +4 & +4 & +4 & +4 & +4 \\
\hline & 13 & $\begin{array}{l}\text { For best practice for Street Furniture to perform its } \\
\text { functions, considerations have been taken to be visible } \\
\text { and with suitably chosen colors. Each item has, in } \\
\text { contrast to its environment and in bright colors as well. }\end{array}$ & +4 & +4 & +4 & +4 & +4 \\
\hline & 14 & $\begin{array}{l}\text { Hi-Tec senores will be installed among Street Furniture } \\
\text { as units for measurement and monitoring air quality, } \\
\text { pedestrian traffic, in cases of emergencies, and pollution. }\end{array}$ & +4 & +4 & +4 & 3 & 3 \\
\hline & 15 & $\begin{array}{l}\text { Functions of street lights will have the ability to } \\
\text { increase/decrease the lighting levels by control } \\
\text { management system via Hi-Tec digital tool. }\end{array}$ & +4 & +4 & +4 & 3 & 3 \\
\hline \multirow[t]{3}{*}{$\begin{array}{l}\text { Functional \& } \\
\text { Technical } \\
\text { Features }\end{array}$} & 16 & $\begin{array}{l}\text { One of the most uses of digital technology comes in the } \\
\text { form of the popular cell phone market and smart phone } \\
\text { booths. These types of digital technology are included } \\
\text { within the city planning for Street Furniture. }\end{array}$ & +4 & +4 & +4 & +4 & +4 \\
\hline & 17 & $\begin{array}{l}\text { The last updated information boards, maps and posts will } \\
\text { be installed in "The New City" to enable getting data and } \\
\text { information via intelligent Street Furniture }\end{array}$ & +4 & +4 & +4 & +4 & +4 \\
\hline & 18 & $\begin{array}{l}\text { All considerations for the ideal placement of Street } \\
\text { Furniture based on the best practice are considered } \\
\text { during the design phase. }\end{array}$ & +4 & +4 & +4 & 3 & 3 \\
\hline $\begin{array}{l}\text { Power, } \\
\text { Energy \& } \\
\text { Lighting }\end{array}$ & 19 & $\begin{array}{l}\text { The planning will use integrated light-emitting diode } \\
\text { (LED) light fixture in the new city's streets. }\end{array}$ & +4 & +4 & +4 & +4 & +4 \\
\hline $\begin{array}{l}\text { Topic of } \\
\text { Statement }\end{array}$ & No. & Q-Statements & $\mathbf{a}$ & $\mathbf{b}$ & c & d & $\mathbf{e}$ \\
\hline \multirow[t]{3}{*}{$\begin{array}{l}\text { Power, } \\
\text { Energy \& } \\
\text { Lighting }\end{array}$} & 20 & $\begin{array}{l}\text { All advertising boards, signs and billboards designed as } \\
\text { devices using (LED) digital furniture for advertising. }\end{array}$ & +4 & +4 & +4 & +4 & +4 \\
\hline & 21 & $\begin{array}{l}\text { With the massive demand and subsequent explosion of } \\
\text { data usage, more wireless network infrastructure } \\
\text { companies (i.e. Orange-Vodafone-Etisalat) and others to } \\
\text { come, they are using the last technology of } 4 \mathrm{G} \text { in the } \\
\text { region. The proper coordination has been made and } \\
\text { arranged among them to collaborate in the data-sharing } \\
\text { for efficient communication protocols serving Street } \\
\text { Furniture. }\end{array}$ & +4 & +4 & +4 & +4 & +4 \\
\hline & 22 & $\begin{array}{l}\text { Solar energy, as the best system in operation, } \\
\text { maintenance and saving costs, is deployed with utmost } \\
\text { activities. }\end{array}$ & +4 & +4 & +4 & 3 & 3 \\
\hline \multirow[t]{2}{*}{ Unity } & 23 & $\begin{array}{l}\text { The planning of the city considered all aspects of the } \\
\text { unity of the streets, by placing it in good locations based } \\
\text { on the norms or the standards. The climate also must be } \\
\text { evaluated carefully, should be in color harmony, easily } \\
\text { maintained and social environments and other } \\
\text { considerations that of these have direct impact on the } \\
\text { unity of Street Furniture and have periodic maintenance } \\
\text { work done on it. }\end{array}$ & +4 & +4 & 3 & 3 & 3 \\
\hline & 24 & $\begin{array}{l}\text { There is an importance of having a number of } \\
\text { international companies, advertising agencies provides its } \\
\text { design experience to submit their proposed intelligent } \\
\text { furniture as one of the planning elements that will incur } \\
\text { revenue for the city. }\end{array}$ & +4 & +4 & +4 & 3 & 3 \\
\hline People & 25 & Responsive Street Furniture could make streets more & +4 & +4 & 3 & 3 & 3 \\
\hline
\end{tabular}




\begin{tabular}{|l|c|l|c|c|c|c|c|}
\hline Oriented & & usable for everyone providing assurance for its benefits. & & & & \\
\cline { 2 - 7 } & 26 & $\begin{array}{l}\text { Street Furniture will be designed to be easily recognized } \\
\text { and understood the users. }\end{array}$ & +4 & +4 & +4 & +4 & +4 \\
\cline { 2 - 7 } & 27 & $\begin{array}{l}\text { People would find Street Furniture more modern, } \\
\text { pleasant. It will be in good shapes, colors, fine texture- } \\
\text { surfaces, and smooth surfaces designed to ensure their } \\
\text { consent, easy usage, ease of maintenance and in a } \\
\text { suitability manners. }\end{array}$ & +4 & +4 & 3 & 3 \\
\hline
\end{tabular}

Interpretation of the Factors - Q-Table for Street Furniture:

Results based on calculated factors revealed the following: totally agree / or full consent (i.e. +4 ranks) for the two segments is $70 \%$ where the perspectives that agreed (i.e. $+3 \&+2$ ) are $22 \%$. Last but not least, other perspectives less than agreeing (-4\&-3\&-2 ranks) are of $7 \%$ as shown in the below inverted pyramidal, Q-Table:

\begin{tabular}{|c|c|c|c|c|c|c|c|c|c|c|c|}
\hline \multicolumn{6}{|c|}{ FULL DISAGREE SOUND \& LESS DISAGREE } & \multicolumn{3}{|c|}{ SOUND \& LESS AGREEE } & \multicolumn{3}{|c|}{ FULL AGREE } \\
\hline Segment / Scale & -4 & -3 & -2 & -1 & $\mathbf{0}$ & +1 & +2 & +3 & +4 & Total & Factor \\
\hline Government Perspectives & 5 & 1 & 0 & 0 & 0 & 0 & 0 & 4 & 71 & 81 & 0.33 \\
\hline Non-Government Perspectives & 2 & 2 & 0 & 0 & 0 & 0 & 0 & 26 & 24 & 54 & 0.22 \\
\hline Pyramidal Q-Table Fig 19 & & & & & & & & & & & \\
\hline
\end{tabular}

As shown in Figure 19, Using the Excel statistical as simple sample tool analysis program, the data for Street Furniture were analyzed using the relevant basic statistical processes (i.e. concluded factors of 0.33 \& 0.22 for Governmental and Non-Governmental officers respectively) all relationships between the data were also analyzed; and with the information obtained from the questionnaires built based on Q-Statements conclude that concept, factors, elements of Street Furniture are being considered and properly accounted for within the phase of planning but will not be in phase 1 of the project but within late phases as originally planned for.

\section{Analysis of Street Furniture Results:}

Total Q-statements for segment of Street Furniture are based on 27 statements delivered, discussed and obtained its perspectives from the participants, having a total of 243 ranges of expected responds (9 ranks).

Responds received are summarized as follows:

Thus, positive consents and agreed upon opinions were aggregated and concluded major topics related to the following:

- Best, updated and last technology will be used during designing most of Street Furniture.

- Implement, focusing on application of ICT technologies and multiuser devices.

- Steel material will be used due to its sustainability durable, resistant to rust and requires minor maintenance.

- Traffic systems in all streets will be equipped by multifunctional digital display.

- Green parks, landscape, seating benches and public art were accounted for in the planning.

- Hi-Tec senores considered among Street Furniture as unit for measurement, control and monitoring air quality, pedestrian traffic, in cases of emergencies, and pollution.

- LED lighting systems are applied and functioning in street lights posts having the ability for increase/decrease the lighting levels by control management system via Hi-Tec digital tool.

- The last technology of 4G, proper coordination have been made and arranged among them to collaborate and data-sharing for efficient communication protocols serving the streets.

Whilst other answers away from consent and agreement opinions due to planning have not being completed and agreed upon by the authorities, as follows:

- Components of fully responsive Street Furniture may not by applying in all areas, since that involves high cost and manufacturing features to be built-in and installed.

- International companies and advertising agencies may have less chance to win applying their Hi-Tec advertisements over Street Furniture in "New Cairo Administration Capital" compared to Egyptian Companies in the market.

- Some constrains may exist, when placing the Street Furniture in certain areas.

- Responsibility tasks for Street Furniture maintenance is not yet concluded and agree upon within the city administrators. Good maintenance plan equal valid and sound sustainablilty. 


\subsection{Conclusions Section:}

\subsubsection{Research Findings:}

\section{For "New Cairo Administration Capital" as a Smart City:}

We found out that the overall planning is achieved in suitable aesthetic concerns in designing "New Cairo Administration Capital", throughout Islamic history manner as base for futuristic planning done in all residences buildings. This creates a meaningful output of Egyptian identity serving the overall objectives aligned with EGYPT 2020-2030 taking as a whole, and its tangible outcomes that expected to achieve. The basic six characteristics of Smart City have been properly applied. We have assured that each initiative has been implemented properly as planned as well as accompanying with the international rules and guidelines of the Smart City. So, we focused on three of these characteristics that are having great impact and valid concerns to all of the planners. The three characteristics cover the following:

- Smart Economy: This conceptual characteristic has been applied, utilized to synchronize, optimize city’s investments in green and broadband economies. The investigation of critical city's resources that will contribute to its readiness to smart vision is a crucial preliminary planning step being done and concluded.

- Smart Governance: All requirements for smart governance have been implemented, like including the decision making participation, public and social services, transparency, democratic processes, interconnection between the governmental organization and administrations, and improving community access to services as well as close involvement, monitoring and following up procedures taken by the highest level of the authority in Egypt.

- Smart Environment: the new capital is well-designed to install, operate and monitor pollution and all related sustainable technologies in order to reach lower levels of energy consumption having the edge of green environment.

\section{For Street Furniture in "New Cairo Administration Capital":}

The obtained results have pointed out a strong relationship between the Street Furniture layouts and the technical fixtures. The related materials counted and highlighted the need to pay attention to studies of new designs concerning the smart furniture in Egypt. Street Furniture is designed in unity, and this gives it an identity and connection to the location. The function of the Street Furniture is not just an object of use, art, or communication. Items of Street Furniture are the designed elements not only for beautification purposes, but to provide comfort, transportation, relaxation, entertainment and protection from the outside effects.

\subsubsection{Conclusions:}

This Conceptual Planning Model (CPM) could be the founding documentation for a Smart City master plan as a map depicting some concepts that might be applied to smart innovation, broadband economy, and innovative urban ecosystems. It examines, respectively, all aspects of designing Street Furniture within a city addressing a mixture of planning priorities in a reference model. It is a combination of various basic elements and factors for crucial considerations that could be used to evaluate Egypt or any other country within the region- its innovative capacity in identifying complements and inconsistencies in Street Furniture' master planning. Therefore, the city master planning should contain the innovative characteristics that contribute to a green, sustainable Smart City growth, which was the focal point of the reference model. Smart City planners working in field of Street Furniture could use the reference planning model as provided from the study to:

- Define the conceptual layout of the Street Furniture planning procedures and describe innovative characteristics and elements of urbanism.

- As Street Furniture come in different shapes and sizes, this reference model for planning should be tailored to local / national urban innovative characters integrating all layers of the model.

- Smart City planners could formulate a six-layer planning agenda based on the local features.

- Utilize the synchronization and optimization of Egypt's investments in the green and broadband economies.

- Investigation of critical Cairo's resources that will contribute to its readiness to the smart vision.

- Prevent unsustainable investments to build upon the socio-technical compliance in the Street Furniture course of action.

\subsubsection{Recommendations:}

Based on our findings, we are suggesting a number of recommendations to be considered within the next planning and designing future Smart Cities in Egypt, based on what have been studied, concluded and implemented: 
A. Future research steps should be considered towards the refinement of the smart innovation model into a "system in systems" model that will mirror -in details- the Smart City processes. Following a systemic approach, the model should be adaptive as far as inputs, outputs, and processing's to the local context of a Smart City.

B. Key performance indicators should be explored for sustainability, competitiveness, and employment generation.

C. A process-oriented evaluation model could be developed based on the systemic Smart City performance that will contest the existing Smart City benchmarking schemas in order to enhance the planning process and to overcome any faced constrains during the implementation of the New Cairo Administration Capitals.

\section{Acknowledgements:}

The conducted Q survey in this research is done by the valuable participation of the following key governmental and non-governmental officials based on their appreciated contribution to the brainstorming and meetings sessions through the preparation phase as well as when submitting its final results and conclusions:

- Mr. Wael Mousa

- Dr. Ahmed Farouk

Assistant to Ministry of Housing, Utilities and Urban Development,

Ministry Advisor for National Projects - Ministry of Investment,

- Eng. Mohamed Arab

- Eng. Safwat Sobhy

Advisor to the National Regulatory Authority Telecommunications

- Dr. Ayman Ashour

CEO, Orascom for Construction Industries, OCI

Dean of Faculty of Engineering,

\section{List of Abbreviations:}

- ICT Information and Communication Technologies

- IT Information Techology

- ITSM IT service management

- UK United Kingdom

- UAE United Arab Emirates

- GDP Gross Domestic Product

- LED Light Emitting Diode

- CPM Conceptual Planning Model

- LLDPE Linear low-density polyethylene

\section{References:}

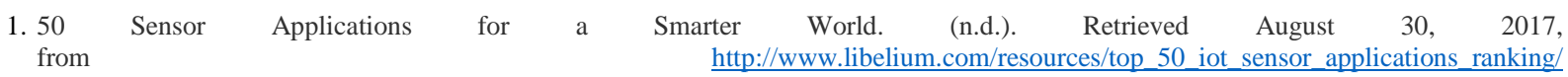

2. Bartolini. S. (2009) "Smart Sensors for Interoperable Smart Environment“- PhD, UNIVERSITÀ DI Dr. Joon Sik Kim, Xi'an Jiaotong Liverpool University, Mapping Conflicts in the Development of Smart Cities: the Experience of Using Q Methodology for Smart, Gusu Project, Suzhou, China, 2016, CORP2016_13.pdf, pages. 1-10

3. BOLOGNA, p. 80 (Table 5.3) http://amsdottorato.unibo.it/23D360A0-8FEC-4637-A7FC-BD4C2AFA9319/FinalDownload/DownloadId337A21BDD2E613292EFBC428A1D24AD5/23D360A0-8FEC-4637-A7FC-BD4C2AFA9319/2576/1/Bartolini_Sara_tesi.pdf

4. BOSTON TREEPODS 2011. (n.d.). Retrieved August 30, 2017, from http://www.shiftboston.org/competitions/2011 treepods.php

5. China Development Bank Capital, 2015, "Six Smart Guidelines, CDBC's Green and Smart Urban Development Guidelines", Green \& Smart, Six-Smart Guidelines_2.pdf, p 14-18

6. CITY OF BALLARAT, (2013) Urban Design Manual,"Part A: Street \& Park Furniture Guidelines",street_and-park_furniture_3.pdf - p 9

7. Dent \& Leslie, "Material Innovation Architecture", 2014, UK in Thames \& Hudson Ltd.P 104-105

8. Donlad Watson, Alan Plattes, Robert Shibley, 2003, "Time-Saver Standards for Urban Design", McGraw-Hill Companies. p 6.5 - 4 \& p 7.9, $1-7$

9. Dr. Joon Sik Kim, Xi'an Jiaotong - Liverpool University, Mapping Conflicts in the Development of Smart Cities: the Experience of Using Q Methodology for Smart, Gusu Project, Suzhou, China, 2016, CORP2016_13.pdf, pages. 1-10

10. European Smart Cities. (n.d.). Retrieved August 30, 2017, from http://www.smart-cities.eu/ranking.html

11. European Union, EU rankings,

12. Ghorab. P, (2014) , Istanbul, Turkey, "Evaluation of Street Furniture according to basic design principles", Design Principles Materials, p.6

13. Hawksworth.J. (2016.). The World in 2050. Retrieved August 30, 2017, from https://www.pwc.com/gx/en/issues/economy/theworld-in-2050.html

14. How IoT Technology is Transforming Businesses - Ericsson. (2017, August 16). Retrieved August 30, 2017, from https://www.ericsson.com/spotlight/services/connected-bus-stop-for-a-better-commuter-experience

http://smart-cities.eu/ranking.html

http://www.coroflot.com/rachel_pownall/modular-street-furniture

http://www.rossatkin.com/wp/?portfolio=responsive-street-furniture

http://www.un-documents.net/ocf-01.htm\#1 
15. MANVILLE, COCHRANE, CAVE, (2014) RAND Europe, Mapping Smart Cities in the EU, 2014, IPOL-ITRE_ET 507480_EN_2.pdf, p.9

16. Modular Street Furniture by Rachel Pownall at Coroflot.com. (n.d.). Retrieved August 30, 2017, from http://www.coroflot.com/rachel_pownall/modular-street-furniture

17. New Jersey Department of Transportation, 2008 (USA) Pennsylvania Department of Transportation

18. New Jersey Department of Transportation, 2008, USA, Pennsylvania Department of Transportation

19. Peyman Ghorab, 2014 , Istanbul, Turkey, "Evaluation of Street Furniture according to basic design principles", Design Principles - Materials, p.6

20. Plan of Implementation of the World Summit on Sustainable Development

21. Rachel Pownall, "Modular Street Furniture", 2008,

22. Responsive Street Furniture. (n.d.). Retrieved August 30, 2017, from http://www.rossatkin.com/wp/?portfolio=responsive-streetfurniture

23. Ross Atkin, 2012, Associates, Research, design and development,

24. Rudenko, A. (2013, December 18). What a smart city of the future will look like? Learn 7 trends in urban living for 2014. Retrieved August 30, 2017, from http://popsop.com/2013/12/what-a-smart-city-of-the-future-will-look-like-learn-7-trends-in-urban-living-for-2014/

25. S. (2016, July 3). Region's first smart street unveiled in Dubai. Retrieved from http://www.emirates247.com/news/emirates/region-s-first-smart-street-unveiled-in-dubai-click-for-where-2016-07-03-1.634798

26. Sara Bartolini, 2009, "Smart Sensors for Interoperable Smart Environment“- PhD, UNIVERSITÀ DI BOLOGNA, p. 80 (Table 5.3) http://amsdottorato.unibo.it/23D360A0-8FEC-4637-A7FC-BD4C2AFA9319/FinalDownload/DownloadId-

337A21BDD2E613292EFBC428A1D24AD5/23D360A0-8FEC-4637-A7FC-BD4C2AFA9319/2576/1/Bartolini_Sara_tesi.pdf

27. Shillong misses 'Smart City' list for the fourth time. (n.d.). Retrieved August 30, 2017, from https://thenortheasttoday.com/tag/smart$\underline{\text { city/ }}$

28. Smart city lighting The humble lamp post goes digital. (2015, June 10). Retrieved August 30, 2017, from http://gelookahead.economist.com/smart-city-lighting/

29. Tulpi.nl, T. (n.d.). Seat. Retrieved August 30, 2017, from http://www.tulpi.nl/tulpi-seat/

30. UN Commission on Science and Technology for Development, "Issues Research on Smart Cities and Infrastructure", 2016, p. 11, http://unctad.org/meetings/en/SessionalDocuments/CSTD_2015_Issuespaper_Theme1_SmartCitiesandInfra_en.pdf

31. United Nations UN “Our Common Future” Chapter 1: A Threatened Future, clause 49,

32. Watson, Plattes, Shibley, (2003) "Time-Saver Standards for Urban Design", McGraw-Hill Companies. p 6.5 - 4 \& p 7.9, 1-7

\section{A. Media \& Newspapers:}

The following contacts have serval announcemets via press, media and newspapers that were considered within the study for thier value technical and operational information given to the press from key officials in various fields of businesses as follows:

Eng. Ismaiel Saeid

Dr. Mohamed Mostafa

Head of Planning \& Excution Sector at Egyptian Telecom. Co.

Mr. Mohamed Nasseim

International Business Director at SHAKER Co.

Representaive General Manager at Urban Communities Authority

- $\quad$ Eng. Mahmoud ElShenawy

Head of Construction Division of Egyptian Espanish Co.

Mr. Mohamed Fouda

Administration Manager at New Capital Company 